\title{
ZUSGS
}

Jins

Prepared in cooperation with the Bureau of Reclamation, Yakama Nation, and the

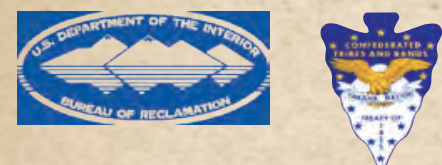

Washington State Department of Ecology

Estimates of Ground-Water Recharge to the Yakima River Basin Aquifer System, Washington, for Predevelopment and Current Land-Use and Land-Cover Conditions

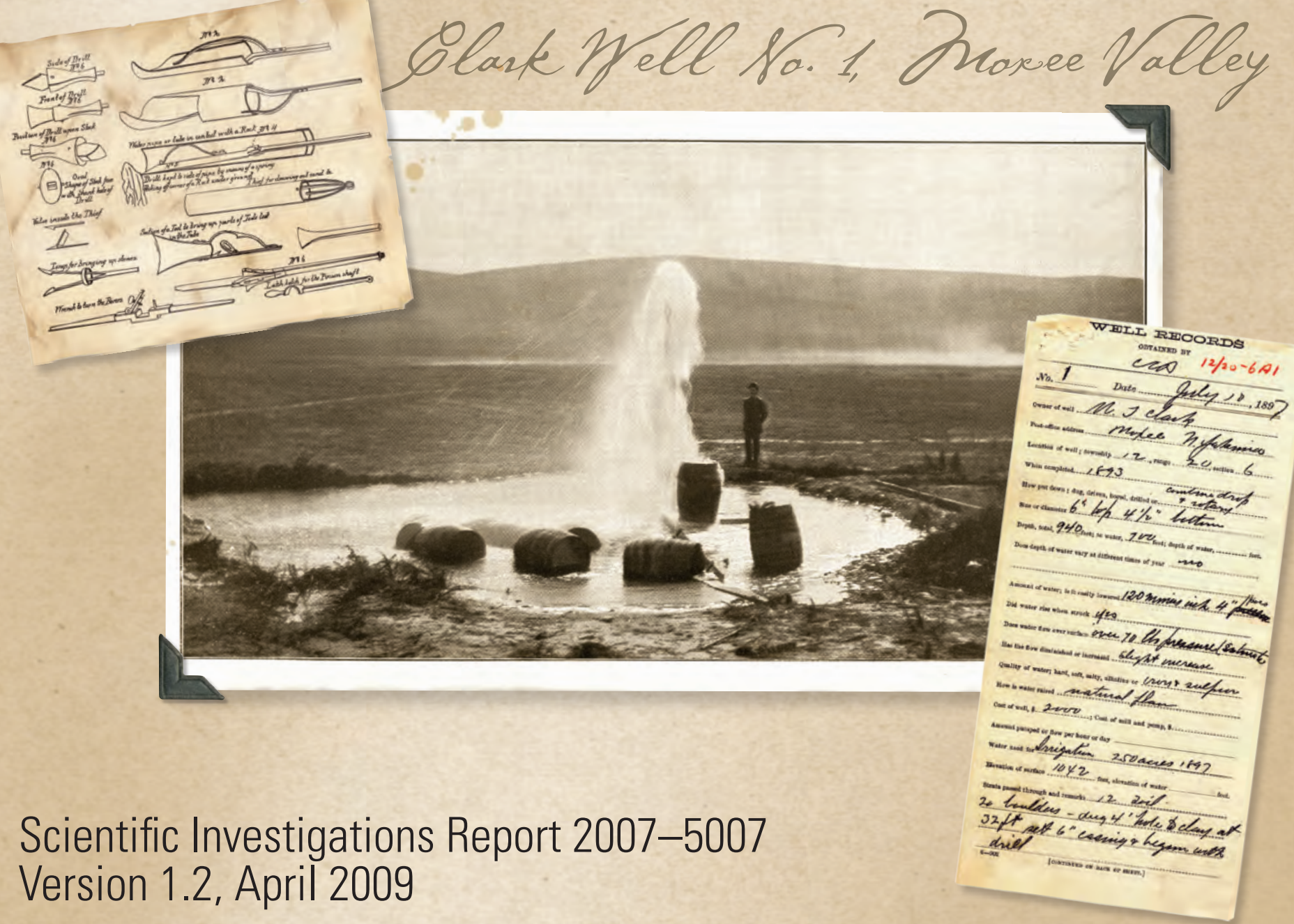

U.S. Department of the Interior

U.S. Geological Survey 
Cover: Photograph of Clark Well No. 1, located on the north side of the Moxee Valley in North Yakima, Washington. The well is located in township 12 north, range 20 east, section 6 . The well was drilled to a depth of 940 feet into an artesian zone of the Ellensburg Formation, and completed in 1897 at a cost of $\$ 2,000$. The original flow from the well was estimated at about 600 gallons per minute, and was used to irrigate 250 acres in 1900 and supplied water to 8 small ranches with an additional 47 acres of irrigation. (Photograph was taken by E.E. James in 1897, and was printed in 1901 in the U.S. Geological Survey Water-Supply and Irrigation Paper 55.) 


\section{Estimates of Ground-Water Recharge to the Yakima River Basin Aquifer System, Washington, for Predevelopment and Current Land-Use and Land-Cover Conditions}

By J.J. Vaccaro and T.D. Olsen

Prepared in cooperation with the Bureau of Reclamation,

Yakama Nation, and

Washington State Department of Ecology

Scientific Investigations Report 2007-5007

Version 1.2, April 2009 


\title{
U.S. Department of the Interior DIRK KEMPTHORNE, Secretary
}

\author{
U.S. Geological Survey \\ Mark D. Myers, Director
}

\section{U.S. Geological Survey, Reston, Virginia: 2007}

For product and ordering information:

World Wide Web: http://www.usgs.gov/pubprod

Telephone: 1-888-ASK-USGS

For more information on the USGS--the Federal source for science about the Earth, its natural and living resources, natural hazards, and the environment:

World Wide Web: http://www.usgs.gov

Telephone: 1-888-ASK-USGS

Any use of trade, product, or firm names is for descriptive purposes only and does not imply endorsement by the U.S. Government.

Although this report is in the public domain, permission must be secured from the individual copyright owners to reproduce any copyrighted materials contained within this report.

Suggested citation:

Vaccaro J.J., and Olsen, T.D., 2007, Estimates of ground-water recharge to the Yakima River Basin aquifer system, Washington, for predevelopment and current land-use and land-cover conditions: U.S. Geological Survey Scientific Investigations Report 2007-5007, 30 p. 


\section{Contents}

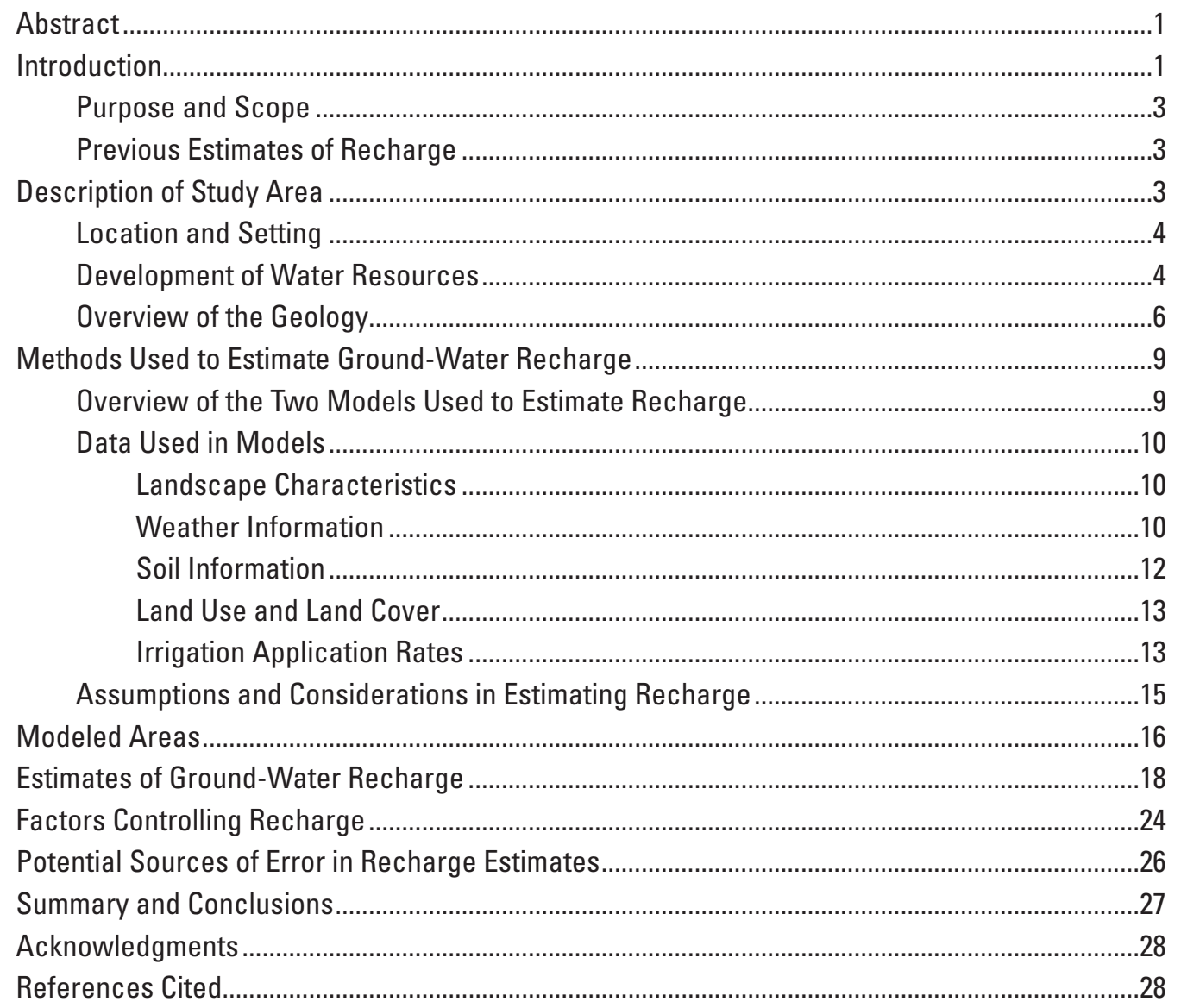




\section{Figures}

Figure 1. Map showing the Yakima River Basin, Washington $\ldots \ldots \ldots \ldots \ldots \ldots \ldots \ldots \ldots \ldots \ldots \ldots \ldots \ldots \ldots \ldots \ldots \ldots$

Figure 2. Map showing land use and land cover, Yakima River Basin, Washington, 1999

Figure 3. Schematic diagram showing selected tributaries, diversion canals, return flows, and stream-gaging stations, Yakima River Basin, Washington

Figure 4. Map showing simplified surficial geology of the Yakima River Basin, Washington

Figure 5. Map showing location of weather-data sites and distribution of mean annual precipitation, Yakima River Basin, Washington

Figure 6. Map showing surface-water irrigation districts, Yakima River Basin, Washington

Figure 7. Map showing areas modeled to estimate recharge for predevelopment conditions, Yakima River Basin, Washington.....

Figure 8. Map showing areas modeled to estimate recharge for current conditions, Yakima River Basin, Washington

Figure 9. Map showing spatial distribution of mean annual recharge for predevelopment conditions, Yakima River Basin, Washington

Figure 10. Map showing spatial distribution of mean annual recharge for current conditions, Yakima River Basin, Washington

Figure 11. Map showing spatial distribution of mean annual recharge for predevelopment conditions in the Ahtanum area, Yakima River Basin, Washington

Figure 12. Map showing spatial distribution of mean annual recharge for current conditions in the Ahtanum area, Yakima River Basin, Washington

Figure 13. Graph showing calculated annual values of selected water-budget components for the lower Naches area

Figure 14. Graph showing relation between mean annual recharge and the mean annual total water input (precipitation or precipitation plus irrigation) for the modeled areas for predevelopment and current conditions

Figure 15. Graph showing relation between mean annual recharge and the ratio of the total quantity of water that can be stored in the root zone to the total water input for the areas modeled using the Deep Percolation Model for predevelopment and current conditions

Figure 16. Graph showing annual precipitation and estimated predevelopment recharge for the Prosser area, Yakima River Basin, Washington

\section{Tables}

Table 1. Characteristics of the modeled areas, Yakima River Basin, Washington $\quad \ldots \ldots \ldots \ldots 12$

Table 2. Summary of estimates of mean annual recharge for the modeled areas, Yakima River Basin, Washington 


\section{Conversion Factors, Datums, and Abbreviations and Acronyms}

Conversion Factors

\begin{tabular}{lcl}
\hline Multiply & By & To obtain \\
\hline acre & 4,047 & square meter \\
acre-foot per year (acre-ft/yr) & 1,233 & cubic meter per year \\
cubic foot $\left(\mathrm{ft}^{3}\right)$ & 0.02832 & cubic meter \\
cubic foot per second $\left(\mathrm{ft}^{3} / \mathrm{s}\right)$ & 0.02832 & cubic meter per second \\
gallon per day (gal/d) & 0.003785 & cubic meter per day \\
inch (in.) & 2.54 & centimeter \\
inch (in.) & 25.4 & millimeter \\
inch per year (in/yr) & 2.54 & centimeter per year \\
foot (ft) & 0.3048 & meter \\
mile (mi) & 1.609 & kilometer \\
million gallons per day (Mgal/d) & 0.04381 & cubic meter per second \\
section $\left(640 \mathrm{acres}^{2}\right.$ or $1 \mathrm{square} \mathrm{mile)}$ & 259.0 & square hectometer \\
square foot $\left(\mathrm{ft}^{2}\right)$ & 0.09290 & square meter \\
square inch $\left(\mathrm{in}^{2}\right)$ & 6.452 & square centimeter \\
square mile $\left(\mathrm{mi}^{2}\right)$ & 2.590 & square kilometer \\
\hline
\end{tabular}

Temperature in degrees Celsius $\left({ }^{\circ} \mathrm{C}\right)$ may be converted to degrees Fahrenheit $\left({ }^{\circ} \mathrm{F}\right)$ as follows:

$$
{ }^{\circ} \mathrm{F}=\left(1.8 x^{\circ} \mathrm{C}\right)+32 .
$$

Temperature in degrees Fahrenheit $\left({ }^{\circ} \mathrm{F}\right)$ may be converted to degrees Celsius $\left({ }^{\circ} \mathrm{C}\right)$ as follows:

${ }^{\circ} \mathrm{C}=\left({ }^{\circ} \mathrm{F}-32\right) / 1.8$.

\section{Datums}

Vertical coordinate information is referenced to the North American Vertical Datum of 1988 (NAVD 88).

Horizontal coordinate information is referenced to the North American Datum of 1983 (NAD 83).

Altitude, as used in this report, refers to distance above the vertical datum. 


\section{Conversion Factors, Datums, and Abbreviations and Acronyms-Continued}

Abbreviations or Acronyms

\begin{tabular}{ll}
\hline Abbreviation and Acronym & Meaning \\
\hline AET & actual evapotranspiration \\
CRBG & Columbia River Basalt Group \\
DEM & digital elevation model \\
DOA & Washington State Department of Agriculture \\
DPM & Deep Percolation Model \\
GIS & Geographic Information System \\
HRU & Hydrologic Response Unit \\
I/P & ratio of irrigation to precipitation \\
km & kilometer \\
LULC & land use and land cover \\
m & meter \\
MMS & Modular Modeling System \\
PRMS & Precipitation-Runoff Modeling System \\
PWS & public water supply \\
R/P & ratio of recharge to precipitation \\
R/T & ratio of recharge to total water input \\
Reclamation & Bureau of Reclamation \\
S & quantity of water that root/soil zone can hold \\
SAT & quantity of water above TWAC \\
SOAC & Systems Operations Advisory Committee \\
T & total water input: precipitation plus irrigation \\
TAWC & total available water capacity \\
TWSA & total water supply available \\
USGS & U.S. Geological Survey \\
WaDOE & Washington State Department of Ecology \\
WRIA & Washington State Water Resource Inventory Area \\
WY & water year \\
YN & Yakama Nation \\
\hline &
\end{tabular}




\title{
Estimates of Ground-Water Recharge to the Yakima River Basin Aquifer System, Washington, for Predevelopment and Current Land-Use and Land-Cover Conditions
}

\author{
By J.J. Vaccaro and T.D. Olsen
}

\section{Abstract}

Two models were used to estimate ground-water recharge to the Yakima River Basin aquifer system, Washington for predevelopment (estimate of natural conditions) and current (a multi-year, 1995-2004, composite) land-use and landcover conditions. The models were the Precipitation-Runoff Modeling System (PRMS) and the Deep Percolation Model (DPM) that are contained in the U.S. Geological Survey's Modular Modeling System. Daily values of recharge were estimated for water years 1950-98 using previously developed PRMS-watershed models for four mainly forested upland areas, and for water years 1950-2003 using DPM applied to 17 semiarid to arid areas in the basin.

The mean annual recharge under predevelopment conditions was estimated to be about 11.9 in. or $5,450 \mathrm{ft}^{3} / \mathrm{s}$ (about 3.9 million acre-ft) for the $6,207 \mathrm{mi}^{2}$ in the modeled area. In the modeled areas, recharge ranged from $0.08 \mathrm{in}$. $\left(1.2 \mathrm{ft}^{3} / \mathrm{s}\right)$ to 34 in. $\left(2,825 \mathrm{ft}^{3} / \mathrm{s}\right)$. About 97 percent of the recharge occurred in the 3,667 $\mathrm{mi}^{2}$ area included in the uplandarea models, but much of this quantity is not available to recharge the bedrock hydrogeologic units. Only about 1.0 in., or $187 \mathrm{ft}^{3} / \mathrm{s}$ (about 0.14 million acre-ft), was estimated to occur in the $2,540 \mathrm{mi}^{2}$ area included in the semiarid to arid lowland modeled areas.

The mean annual recharge to the aquifer system under current conditions was estimated to be about 15.6 in., or $7,149 \mathrm{ft}^{3} / \mathrm{s}$ (about 5.2 million acre-ft). The increase in recharge is due to the application of irrigation water to croplands. The annual quantity of irrigation was more than five times the annual precipitation for some of the modeled areas. Mean annual actual evapotranspiration was estimated to have increased from predevelopment conditions by more than $1,700 \mathrm{ft}^{3} / \mathrm{s}$ (about 1.2 million acre- $\mathrm{ft}$ ) due to irrigation.

\section{Introduction}

Surface water in the Yakima River Basin, in south-central Washington (fig. 1) is under adjudication and the amount of surface water available for appropriation is unknown, but there are increasing demands for water for municipal, fisheries, agricultural, industrial, and recreational uses. These demands must be met by ground-water withdrawals and/or by changes in the way water resources are allocated and used. On-going activities in the basin for enhancement of fisheries and obtaining additional water for agriculture may be affected by ground-water withdrawals and by rules implemented under the Endangered Species Act for salmonids that have been either listed or were proposed for listing in the late 1990s. An integrated understanding of the ground-water flow system and its relation to the surface-water resources is needed in order to implement effective water-resources management strategies in the basin. In order to develop this understanding, a study of the Yakima River Basin aquifer system began in June 2000. The study is a cooperative effort of the U.S. Geological Survey (USGS), Bureau of Reclamation (Reclamation), the Yakama Nation (YN), and the Washington State Department of Ecology (WaDOE).

The overall objectives of the study are to fully describe the ground-water flow system and its interaction with and relation to surface water, and to provide baseline information for a management tool-a numerical model. The conceptual model of the flow system and the results of the study can be used to guide and support actions taken by management agencies with respect to ground-water availability and to provide information to other stakeholders and interested parties. The numerical model will be developed as an integrated tool to assess short-term to long-term management activities, including the testing of potential management strategies. 


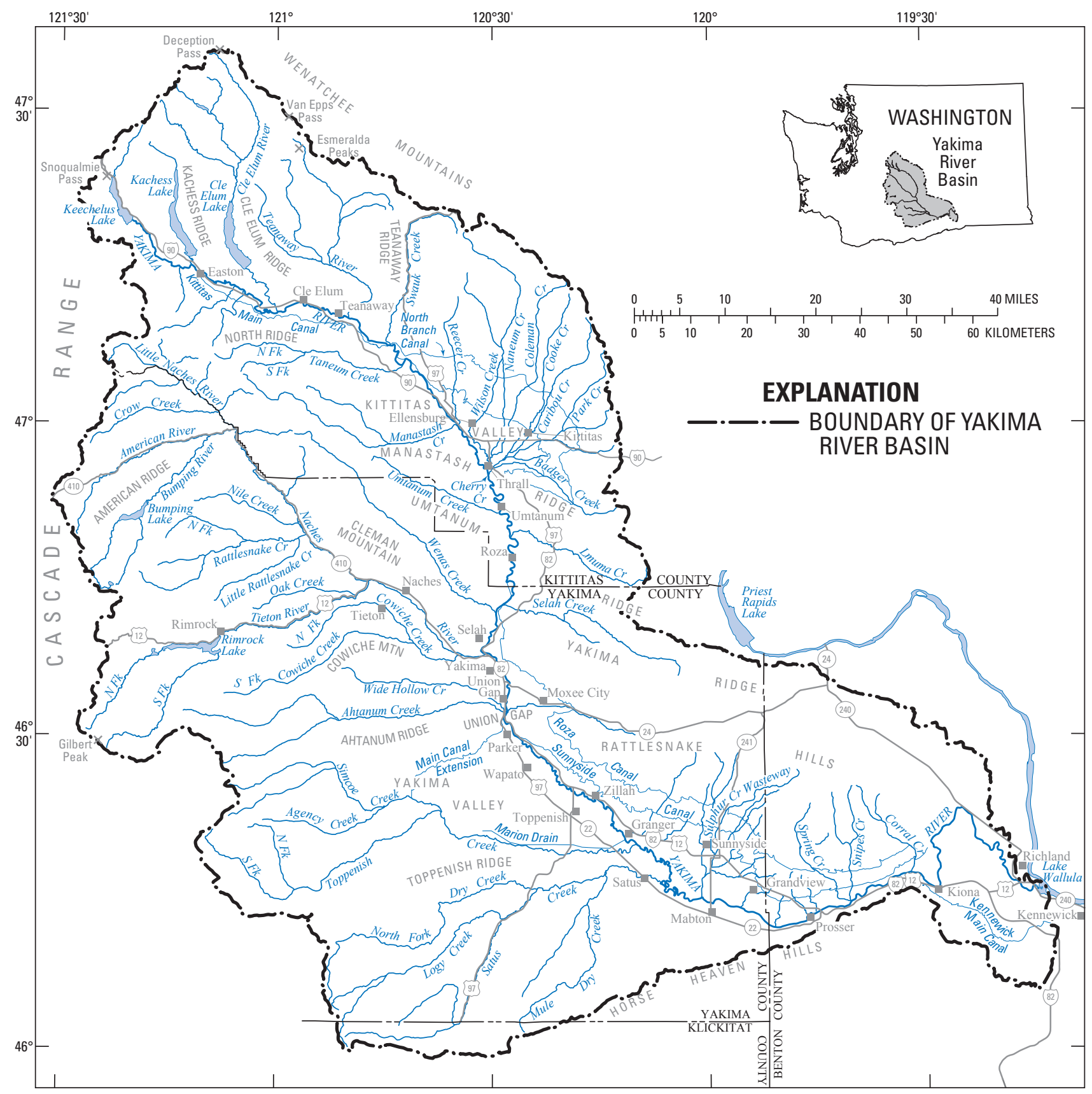

Figure 1. The Yakima River Basin, Washington. 
The study includes three phases. The first phase includes (1) project planning and coordination, (2) compiling, documenting, and assessing available data, and (3) initial data collection. The second phase consists of data collection to support the following Phase 2 work elements: (1) mapping of hydrogeologic units, (2) estimating ground-water pumpage, (3) developing estimates of ground-water recharge, (4) assessing ground water-surface water interchanges, and (5) constructing maps of ground-water levels. Together, these five elements provide the information needed to describe the ground-water flow system, develop the conceptual model, and provide the building blocks for the hydrogeologic framework. In the third phase, six structural basin models and one regional model of the ground-water flow system will be constructed in order to integrate the available information. The numerical models will be used to gain a further understanding of the flow system and its relation to surface water, and to test management strategies.

The results from selected work elements will be described in a series of reports. This report describes the estimates of ground-water recharge to the Yakima River Basin aquifer system, a Phase 2 work element. Recharge is a major control on the flow of ground-water in the aquifer system and on water availability. The estimates of recharge provide information on a little known, but important, water-budget component in the study area. Spatial and temporal estimates of recharge also are needed as input to the ground-water flow models being constructed as part of this study.

\section{Purpose and Scope}

This report presents estimates of mean annual groundwater recharge to the Yakima River Basin aquifer system for predevelopment and current land-use and land-cover (LULC) conditions. Predevelopment conditions are an estimate of LULC conditions prior to any human activities in the basin, and current conditions are representative of a recent multi-year (1995-2004) composite.

The report describes the data and methods used to estimate recharge, the factors controlling recharge, and the potential sources of error in the estimates. For this report, recharge is defined as deep percolation past the bottom of the root zone, or in the case of bare soils as deep percolation through the bottom of the mapped soil depth, herein called the soil zone. Recharge is derived from snowmelt, incident rain on the land surface (including throughfall), irrigation of croplands, and septic-system drainfields.
Hydrologic models have proved to be efficient tools for estimating long-term daily average recharge to an aquifer system under predevelopment and current LULC conditions. Recharge to the Yakima River Basin aquifer system was calculated using two different models for the complete system (18 areas or watersheds covering 6,207 $\mathrm{mi}^{2}$ ) for predevelopment LULC conditions. Predevelopment conditions were estimated by changing the LULC with large human influences to a LULC of sagebrush. Currentcondition recharge was modeled for 16 areas with large human influences, such as irrigated agriculture, highdensity commercial or residential use, and urban land. Thirteen of these 16 areas were the same areas modeled for predevelopment conditions.

Four previously developed watershed models (Mastin and Vaccaro, 2002a) were used to calculate daily values of recharge for upland areas for water years (WY) 1950-98. A soil water-budget model was used to calculate recharge for WYs 1950-2003 for lowland areas with large human influences. The daily values were then aggregated to calculate monthly, annual, mean monthly, and mean annual values. This report principally describes the mean annual values.

\section{Previous Estimates of Recharge}

The most comprehensive previous estimates of recharge to the Yakima River Basin system were made by Bauer and Vaccaro (1990) for the parts of the study area underlain by the Columbia River Basalt Group using the Deep Percolation Model (DPM) (Bauer and Vaccaro, 1987). The DPM was applied to 15 areas or watersheds in the basin, which included most of the irrigated lands in the basin. These areas were generally divided into 1-mi square cells for model simulations. Recharge was estimated for both predevelopment and current LULC conditions for climatic conditions during the period 1956-77. Mean annual recharge for predevelopment conditions was estimated to range from about 0.23 to 10.65 in. for the 15 areas. For current conditions, mean annual recharge was estimated to have increased by more than $15 \mathrm{in}$. in some of the areas irrigated by surface water.

\section{Description of Study Area}

The location and setting of the study area, the development of water resources in the basin, and an overview of the geology are presented to provide a general background for understanding the study area. 


\section{Location and Setting}

The Yakima River Basin aquifer system underlies about 6,200 $\mathrm{mi}^{2}$ in south-central Washington (fig. 1). The Yakima River Basin produces a mean annual unregulated streamflow (adjusted for regulation and without diversions or returns) of about 5,600 ft 35 s (about 4.1 million acre-ft) and a regulated streamflow of about 3,600 ft³/s (about 2.6 million acre-ft). The basin includes three Washington State Water Resource Inventory Areas (WRIA-numbers 37, 38, and 39), part of the Yakama Nation lands, and three ecoregions (Cascades, Eastern Cascades, and Columbia Basin-Omernik, 1987; Cuffney and others, 1997). The basin encompasses parts of four counties (Klickitat, Kittitas, Yakima, and Benton). Almost all of Yakima County, more than 80 percent of Kittitas County, and about 50 percent of the Benton County is in the basin. Less than 1 percent of the basin, principally in an unpopulated upland area, lies in Klickitat County.

The headwaters of the basin are on the upper, humid east slope of the Cascade Range, where the mean annual precipitation is more than $100 \mathrm{in}$. The basin terminates at the confluence of the Yakima and Columbia Rivers in a low-lying, arid area that receives about 6 in. of precipitation per year. Altitudes in the basin range from 400 to nearly 8,000 ft. Eight major rivers and numerous smaller streams are tributary to the Yakima River (fig. 1); the largest tributary is the Naches River. Most of the precipitation in the basin falls during the winter months as snow in the mountains. The mean annual precipitation over the entire basin is about $27 \mathrm{in}$. (about $12,300 \mathrm{ft}^{3} / \mathrm{s}$ or 8.9 million acre-ft). The spatial pattern of mean annual precipitation resembles the pattern of the basin's highly variable topography. The difference between the mean annual precipitation and mean annual unregulated streamflow is $6,400 \mathrm{ft}^{3} / \mathrm{s}$ (about 4.6 million acre-ft); about 53 percent of the precipitation is lost to evapotranspiration under natural conditions.

The basin is separated into several broad valleys by large east-west trending anticlinal ridges. The valley floors are flat and slope gently towards the Yakima River. Few perennial tributary streams traverse these valleys. Most of the population and economic activity occurs in these valleys.

Agriculture is the principal economic activity in the Yakima River Basin. The average annual surface-water demand met by the Reclamation's Yakima Project is about 2.5 million acre-ft; an additional 336,000 acre-ft of demand in the lower river basin is separate from the demand met by the project. Additional surface-water demand that is not met by Reclamation occurs in smaller tributaries and on the large rivers; this demand is based on State appropriated water. More than 95 percent of the demand is for irrigation of about 500,000 acres in the low-lying semiarid to arid parts of the basin (fig. 2). The demand is partly met by storage of nearly 1.1 million acre-ft of water in five Reclamation reservoirs. The major management point for Reclamation is the streamflow gaging station at the Yakima River near Parker. Just upstream of this site, at Union Gap, is the location that is considered the dividing line between the upper (mean annual precipitation of 7 to 125 in.) and lower (mean annual precipitation of 6 to 45 in.) parts of the Yakima River Basin. About 45 percent of the water diverted for irrigation is eventually returned to the river system as surface-water inflows and ground-water discharge, but at varying time-lags (Bureau of Reclamation, 1999). During the low-flow period, these return flows, on average, account for about 75 percent of the streamflow below the streamflow gaging station near Parker. Much of the surface-water demand in the basin below Parker is met by these return flows and not by release of water from the reservoirs. As a result of water use in the basin, the difference between mean annual unregulated and regulated streamflow in the basin is about $2,000 \mathrm{ft}^{3} / \mathrm{s}$, suggesting that some 1.4 million acre-ft of water, or about 17 percent of the precipitation in the basin, is consumptively used-principally by irrigated crops through evapotranspiration.

\section{Development of Water Resources}

Missionaries arrived in the basin in 1848 and established a mission in 1852 on Atanum (now Ahtanum) Creek. They were some of the first non-Indian settlers to use irrigation on a small scale. Miners and cattlemen immigrated to the basin in the 1850s and 1860s, which resulted in a new demand for water. With increased settlement in the mid-1860s, irrigation of the fertile valley bottoms began and the outlying areas were extensively used for stock rearing. One of the first known non-Indian irrigation ditches was constructed in 1867 and diverted water from the Naches River (Parker and Storey, 1913; Flaherty, 1975). Private companies later delivered water through canal systems built between 1880 and 1904 for the irrigation of large areas. The development of irrigated agriculture was made more attractive by the construction of the Northern Pacific Railway, which reached Yakima in December 1884 and provided a means to transport agricultural goods to markets; two years later, the completion of the railway to the Pacific coast provided new and easily accessible markets for agricultural products. The State of Washington was created in 1889, spurring further growth in the basin, especially because the cities of Ellensburg and Yakima were in contention for being the State capital. By 1902 there were about 120,000 acres under mostly surface-water irrigation in the basin (Parker and Storey, 1913; Bureau of Reclamation, 1999). 




Figure 2. Land use and land cover, Yakima River Basin, Washington, 1999. From Fuhrer and others, 2004. 
The Federal Reclamation Act was enacted in 1902 to enable the construction of Federal water projects in the western United States in order to expand the development of the West. In 1905, the Washington State Legislature passed the Reclamation Enabling Act, and the Yakima Federal Reclamation Project was authorized to construct facilities to irrigate about 500,000 acres. As part of the 1905 authorization and extensions, all forms of further appropriation of unappropriated water in the basin were withdrawn (Parker and Storey, 1913). Six dams were constructed as part of the Yakima Project: Bumping Dam in 1910, Kachess Dam in 1912, Clear Creek Dam in 1914, Keechelus Dam in 1917, Tieton Dam (Rimrock Lake) in 1925, and Cle Elum Dam in 1933. The construction of the dams and other irrigation facilities resulted in an extremely complicated surface-water system (fig. 3). These Federal reservoirs provide water storage to meet irrigation requirements of the major irrigation districts at the time of year when the natural streamflow from unregulated streams can no longer meet demands; this time is referred to as the 'storage control' date. Several of the reservoirs also provide instream flows during the winter for the incubation of salmon eggs in the salmon redds (gravel spawning nests).

Legal challenges to water rights resulted in the 1945 Consent Decree (U.S. District Court, 1945) that established the framework of how Reclamation operates the Yakima Project to meet water demands. The Decree determined two classes of rights-nonproratable and proratable. When the total water supply available (TWSA, defined as current available storage in the reservoirs, estimates of unregulated flow, and other sources that are principally return flows) is not sufficient to meet both classes of rights, the proratable (junior) rights are decreased according to the quantity of water available defined by the TWSA. This legally mandated method generally performs well in most years, but is dependent on the accuracy of the TWSA estimate. In some years, for example 1977, problems have arisen because of errors in the TWSA estimate (Kratz, 1978; Glantz, 1982). System management also accounts for defined instream flows at selected target points on the river, and for suggested changes in storage releases recommended by the Systems Operations Advisory Committee (SOAC) — the advisory board of fishery biologists representing the different stakeholders (Systems Operations Advisory Committee, 1999).

The drilling of numerous wells for irrigation was spurred by new (post-1945) well-drilling technologies, legal rulings, and the onset of a multi-year dry period in 1977 (Vaccaro, 1995). Population growth in the basin was, and still is, the driving force behind the increased drilling of shallow domestic wells and deeper public water supply wells. Currently, there are more than 20,000 wells in the basin. More than 70 percent of these wells are shallow, 10-250 ft deep, domestic wells. Based on the digital water-rights database provided by WaDOE (R. Dixon, Washington State Department of Ecology, written commun., 2001) and other information, there are at least 2,874 active ground-water rights associated with the wells in the basin that can collectively withdraw an annual quantity of about 529,231 acre-ft during dry years. The irrigation rights are for the irrigation of about 129,570 acres. There are about 16,600 ground-water claims in the basin; these claims are for some 270,000 acre-ft of ground water (J. Kirk, Washington State Department of Ecology, written commun., 1998). 'A water right claim is a statement of claim to water use that began before the state Water Codes were adopted, and is not covered by a water right permit or certificate. A water right claim does not establish a water right, but only provides documentation of one if it legally exists. Ultimately, the validity of claimed water rights would be determined through general water right adjudications' (Washington State Department of Ecology, 1998). A ground-water claim means a user claims that they were using ground water continuously, prior to 1945, when the State legislature enacted the Ground Water Code, for a particular use.

\section{Overview of the Geology}

The Columbia Plateau has been informally divided into three physiographic subprovinces (Meyers and Price, 1979). The western margin of the Columbia Plateau contains the Yakima Fold Belt subprovince and includes the Yakima River Basin. The Yakima Fold Belt is a highly folded and faulted region, and within the study area it is underlain by various consolidated rocks ranging in age from Precambrian to Tertiary, and unconsolidated materials and volcanic rocks of Quaternary age (fig. 4). In the Yakima River Basin, the headwater areas in the Cascade Range include metamorphic, sedimentary, and intrusive and extrusive igneous rocks. The central, eastern, and southwestern parts of the basin are composed of basalt lava flows of the Columbia River Basalt Group (CRBG) with some intercalated sediments that are discontinuous and weakly consolidated. The lowlands are underlain by unconsolidated and weakly consolidated valley fill comprising glacial, glacio-fluvial, lacustrine, and alluvium deposits that in places exceed 1,000 ft in thickness (Drost and others, 1990). Wind-blown deposits, called loess, occur locally along the lower valley. 

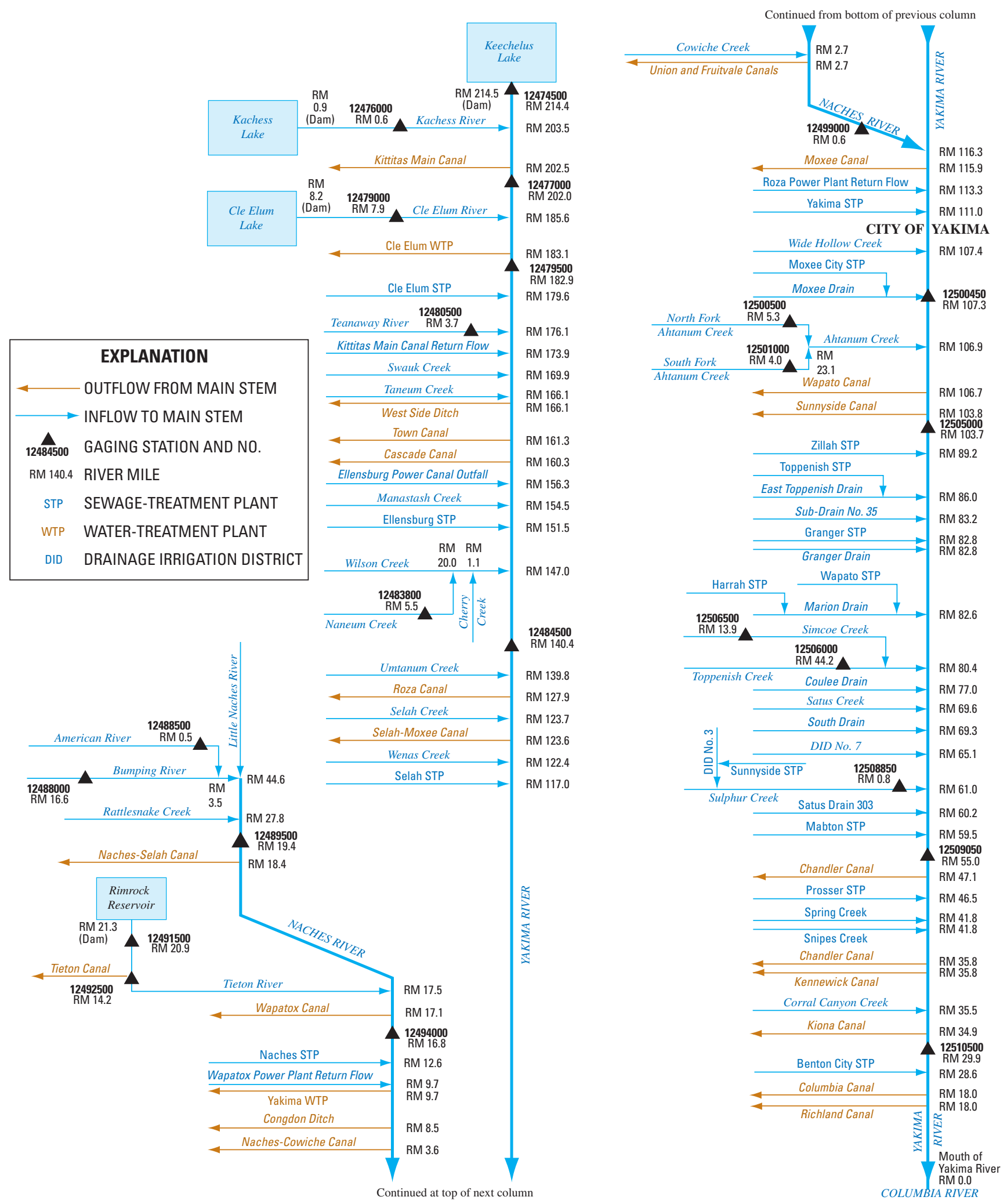

Figure 3. Selected tributaries, diversion canals, return flows, and stream-gaging stations, Yakima River Basin, Washington. 


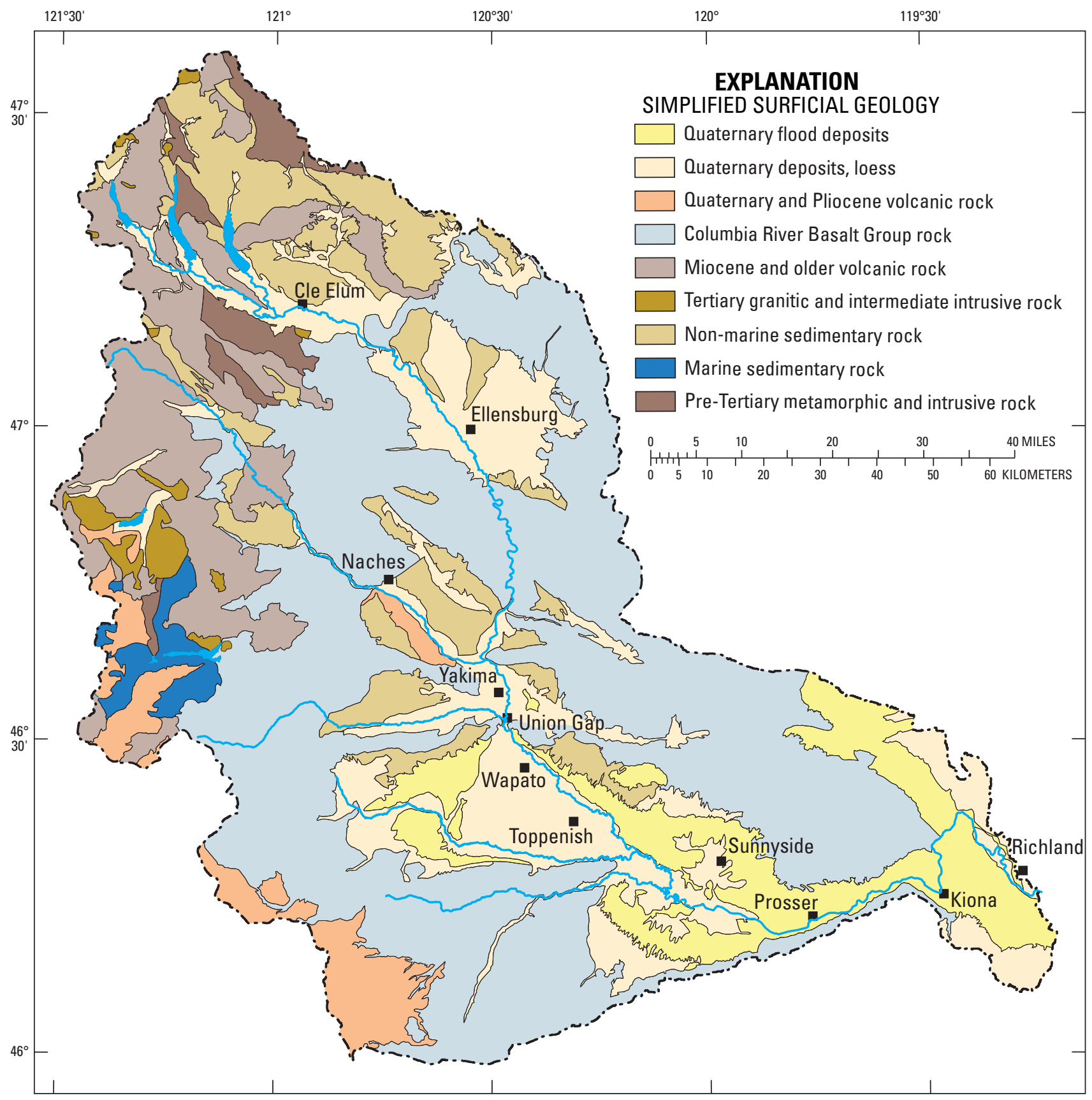

Figure 4. Simplified surficial geology of the Yakima River Basin, Washington. From Fuhrer and others, 1994. 
Valley-fill deposits and basalt lava flows are important for ground-water occurrence in the study area. The basalt consists of a series of flows erupted during various stages of the Miocene Age, from 17 to 6 million years ago. Basalt erupted from fissures in the eastern part of the Columbia Plateau and individual flows range in thickness from a few feet to more than $100 \mathrm{ft}$. The total thickness in the central part of the plateau is estimated to be greater than $10,000 \mathrm{ft}$ (Drost and others, 1990) with a maximum thickness of more than $8,000 \mathrm{ft}$ in the study area. Unlike most of the Columbia Plateau, the CRBG in the Yakima Fold Belt is underlain by sedimentary rocks. The valley-fill deposits were eroded from the Cascade Range and from the east-west-trending anticlinal ridges that were formed by the buckling of the basalt sequence during mid- to late-Miocene time. Much of these deposits are part of the Ellensburg Formation. This formation underlies, intercalates, and overlies the basalts along the western edge, and comprises most of the thickness of the unconsolidated deposits (informally called the overburden; Drost and others, 1990) in the basinal areas. The basins are narrow to large open synclinal valleys between the numerous anticlinal ridges.

The deposition of a thick, upper sequence of sand, gravel, and some fine-grained material is the result of erosion by glacial ice and transport by meltwater streams. Damming of large lakes by glacial ice during the Pleistocene epoch resulted in the deposition of silt and clay beds in parts of the uplands. When the lakes drained, the fine sediments were exposed, subsequently eroded by wind, and deposited over the lower, eastern parts of the study area. Thus, the unconsolidated materials in the basinal areas that are abutting and interbedded with the basalts range in age from Miocene to Holocene.

\section{Methods Used to Estimate Ground-Water Recharge}

\section{Overview of the Two Models Used to Estimate Recharge}

Two models in the USGS's Modular Modeling System (MMS; Leavesley and others, 1996) were used to estimate recharge for the entire aquifer system: Precipitation-Runoff Modeling System (PRMS; Leavesley and others, 1983) and DPM (Vaccaro, 2007). Both models are extensively documented and will not be described in detail here.

The models are driven by daily values for precipitation and for maximum and minimum air temperatures, and partition precipitation into either rain or snow. The models simulate snow accumulation and ablation, plant interception, evapotranspiration, surface runoff, infiltration, water storage in the root or soil zone, and recharge (deep percolation through the bottom of the root or soils zone). The models have similar required input parameters and calculate water balances on the basis of user-defined Hydrologic Response Units (HRUs) into which a watershed or an area is subdivided for model calculations.

PRMS was used to estimate recharge for four, generally wetter, forested upland areas where there are few human activities; these estimates were assumed to be the same for predevelopment and current LULC conditions. PRMS is a physically-based rainfall-runoff watershed model that is fully described and documented in Leavesley and others (1983). The PRMS models were previously constructed (Mastin and Vaccaro, 2002a) as part of the joint USGS and Reclamation Watershed and River System Management Program (U.S. Geological Survey, 1998), and modifications to PRMS for application to the Yakima River Basin are documented in Mastin and Vaccaro (2002b). The models simulate streamflow for estimated unregulated conditions for use in reservoir and river management by Reclamation.

DPM was used to estimate predevelopment and current recharge in 17 areas with extensive human activities, principally agricultural and urban areas. DPM was originally developed by Bauer and Vaccaro (1987) as a tool for estimating daily ground-water recharge over a broad array of landscapes and spatiotemporal scales for the purpose of providing an independent estimate of recharge for ground-water flow models. DPM was later modified by Bauer and Mastin (1997). As part of this study, DPM was modularized and incorporated into MMS (Vaccaro, 2007); the modularization included some modifications. Unlike PRMS, DPM simulates only the land-surface processes and does not simulate the movement of deep percolation below the root or soil zone.

For consistency in calculating recharge between PRMS and DPM, PRMS-recharge was defined as the excess water (deep percolation) leaving the root or soil zone after abstractions by surface runoff and evapotranspiration. The total amount of water that can be stored in the root or soil zone before recharge occurs in both PRMS and DPM is the total available water capacity (TAWC), which is the amount of water that can be stored in the soil column before gravity drainage occurs. TAWC approximates the total unsaturated storage capacity of the root or soil zone because it does not account for the volume of water stored below the wilting point.

The root or soil zone in PRMS is modeled as a single water-storage unit that has an upper part, where both evaporation and transpiration can occur, and a lower part, where only transpiration occurs. The depth of the root or soil zone is determined by the LULC for a HRU. Four LULCs are used in PRMS (bare soils, grasses, shrubs, and trees) and a fifth (water) was added by Mastin and Vaccaro (2002b). A water land cover does not have a root zone, and recharge is assumed to be zero for HRUs with that land cover; 
moisture additions to water HRUs are due to precipitation and abstractions are due to evaporation. For barren land, the root zone is the soil zone and is that upper part of the soil column where bare-soil evaporation occurs (Leavesley and others, 1983).

The root zone in DPM is the depth of the roots for the LULC of a HRU and for bare soils it is the soil zone, which is the depth of the mapped soil column. DPM currently has 31 LULCs that include a variety of crops, such as beans, grapes, orchards, corn, and hops. Recharge is assumed to be zero for land covers of water and impervious areas (barren rocks and built-up areas - urban areas and high-density commercial or residential). The root zone has a temporally constant depth for such covers as forests, orchards, and sagebrush, and expands with plant growth for such covers as beans or corn. The depth of the root zone is limited by the depth to bedrock for shallow soils, and thus may be less than a particular plant's root depth. All plant types in DPM have a default value for the maximum root depth, maximum interception capacity, and maximum foliar cover. Interception capacity is the amount of water that a plant can store on its foliage and it varies greatly by plant type and for some plants, by growth stage. Foliar cover is similar to a leaf area index, and is the percent of shading the plant's foliage provides to the ground; it is used in throughfall and soil evaporation calculations. Users can define these three plant parameters for any plant type contained in DPM because a parameter, such as root depth, can vary depending on a plant's genetic stock, soils, and climatic setting. For some plant types, these three parameters are adjusted daily using a calculated daily plant growth stage.

\section{Data Used in Models}

\section{Landscape Characteristics}

PRMS and DPM require landscape characteristics as input parameters for each HRU. These characteristics are the average altitude, slope and aspect, the area, and the $\mathrm{X}$ - and $y$-locations of the centroid of the HRU. For the PRMS models, a digital elevation model (DEM) with a 208-ft grid-cell size of the basin was used by a GIS (Geographic Information System) interface, termed the GIS Weasel (Leavesley and others, 1997; Viger and others, 1997), to calculate HRU values for these characteristics (Mastin and Vaccaro, 2002a). The GIS Weasel is part of MMS and facilitates model development. For the DPM models, 10-m DEMs (U.S. Geological Survey, 2000) were mosaicked and the landscape characteristics for each HRU in each modeled area were calculated using a
DPM 'plug-in' for the GIS Weasel (R. Viger, U.S. Geological Survey, written commun., 2005).

\section{Weather Information}

Daily values of precipitation and maximum and minimum air temperatures for 36 sites were previously compiled in the MMS-input format for WYs 1950-96 (Mastin and Vaccaro, 2002a). There were 17 National Weather Service sites, 12 Natural Resources and Conservation Service SNOTEL sites, and 7 Reclamation sites. Data from these sites were interpolated by PRMS to the HRUs using a distance-weighted scheme. Daily values from these sites for WYs 1997-98 were later compiled by Mastin (U.S. Geological Survey, written commun., 2002). To develop input for the DPM models, records from 13 sites (fig. 5) were either compiled or extended for WYs 1999-2003. These 13 sites did not include the wetter, high-elevation sites because of their distance from the areas being modeled using DPM.

Mean annual precipitation at the 36 sites ranges from about 7 to $128 \mathrm{in}$. and annual values ranged from about 3 in. to more than $140 \mathrm{in}$. The large differences in mean annual precipitation between weather sites are clearly indicated by the spatial distribution of mean annual precipitation (Daly and Taylor, 1998) (fig. 5). The daily precipitation has ranged from zero to more than 7 in. Mean annual minimum air temperatures were as low as about $20^{\circ} \mathrm{F}$ and mean annual maximum temperatures were as high as $70^{\circ} \mathrm{F}$. Daily minimum air temperatures were as low as $-30^{\circ} \mathrm{F}$ and daily maximum air temperatures were as high as $110^{\circ} \mathrm{F}$.

Adjustments to daily precipitation interpolated from weather sites to a HRU use the ratios of the mean monthly precipitation of the HRU to those at the weather site. Mean monthly precipitation at the weather sites was calculated for the period of record. The mean monthly precipitation at a HRU was calculated using the GIS Weasel 'plug-in' from information of Daly and Taylor (1998), which is the mean monthly precipitation values for 4- by 4-km grid cells. The size of the cells results in large changes across cell boundaries, especially where there are large gradients in monthly precipitation. In turn, there are similar changes in the interpolated precipitation values at the HRUs that are near the grid cell boundaries.

Monthly minimum and maximum lapse rates (temperature change per 1,000 ft change in elevation) for both minimum and maximum air temperatures were calculated from the daily temperature data. These monthly values are based on lapse-rate calculations between all sites for each day for each month for the period 1950-98. 


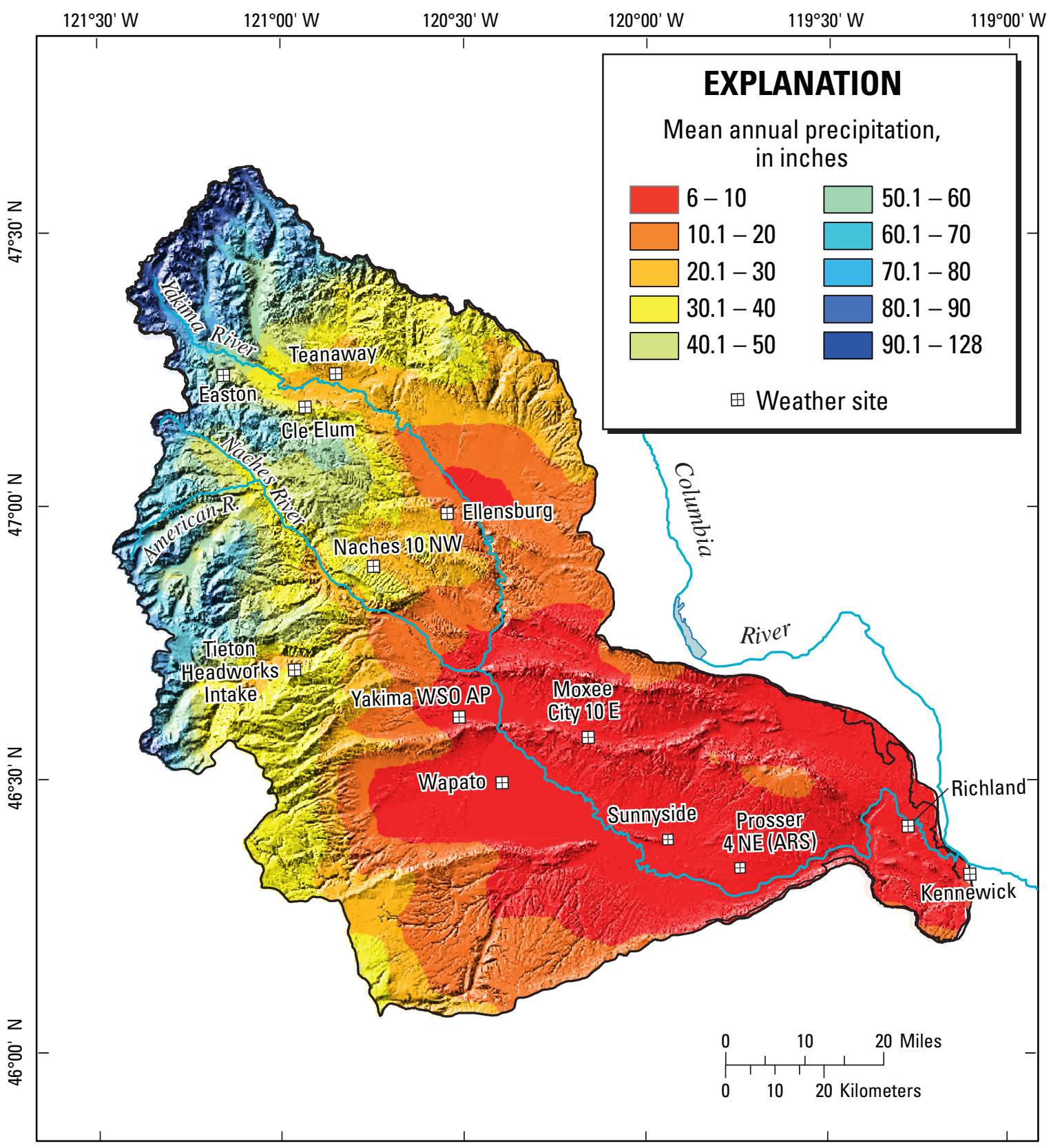

Figure 5. Location of weather-data sites and distribution of mean annual precipitation, Yakima River Basin, Washington. 


\section{Soil Information}

Three soil databases were used in this study. The STATSGO database (U. S. Department of Agriculture, 1994) was used to define the soil properties for the PRMS models and for three of the DPM models; these latter three models were for parts of the upper basin where data from the other databases were unavailable (table 1). For all but two of the remaining DPM models, the SSURGO database (Soil Survey Staff, undated) was used. The remaining two models (for the Yakama Nation irrigated lands) used a SSURGOformatted database (S. Wangemann, Bureau of Indian Affairs, written commun., 2002; table 1). The SSURGO data include information from several survey areas because of the large size of the study area.

The PRMS soil parameters were calculated from the STATSGO database using the GIS Weasel. These parameters include such information as the TAWC, soil depth, the TAWC in the upper part of the root zone where soil evaporation can occur, and soil texture. For the DPM models, soil types were first determined for the three databases. A specified soil type has similar soil attributes throughout and carries these attributes as model input parameters. Thirty-three soil types were defined for the STATSGO database and 119 soil types

Table 1. Characteristics of the modeled areas, Yakima River Basin, Washington.

[Values will not sum due to rounding. Identification No.: Location of area shown on figures 7 and 8. Model: DPM, Deep Percolation Model; PRMS, Precipitation-Runoff Modeling System. Hydrologic Response Unit: (HRU), each area is subdivided by HRUs for calculating water budgets. SIZE: square HRUs were used for the subdivisions in the DPM models and they would not be squares where the boundary of the model area intersected the boundary HRUs. SIZE in feet represents the length of a side of a complete square and SIZE in acres represents the amount of acreage in a complete square. Number of HRUs multiplied by the area of the square HRU will not equal the modeld area (Area). Capacity: TAWC, total available water capacity is the amount of water that can be stored in the root zone between the wilting point and field capacity; SAT, saturated capacity; Total, total water capacity. SAT and Total for Naches, upper Yakima, ToppSatus, and Yak Canyon modeled areas estimated from information for the remaining areas. Soil database: 1 is the SSURGO database and 2 is the STATSGO database. Abbreviations: ${ }^{\circ} \mathrm{F}$, degrees Fahrenheit; $\mathrm{mi}^{2}$, square miles]

\begin{tabular}{|c|c|c|c|c|c|c|c|c|c|c|c|c|c|}
\hline \multirow{3}{*}{ Name } & \multirow{3}{*}{$\begin{array}{c}\text { Identi- } \\
\text { fication } \\
\text { No. }\end{array}$} & \multirow{3}{*}{ Model } & \multicolumn{3}{|c|}{ Hydrologic Response Unit } & \multirow{3}{*}{$\begin{array}{l}\text { Area } \\
\left(\mathrm{mi}^{2}\right)\end{array}$} & \multicolumn{3}{|c|}{ Capacity (inches) } & \multirow{3}{*}{$\begin{array}{l}\text { Precipi- } \\
\text { tation } \\
\text { (inches) }\end{array}$} & \multirow{3}{*}{$\begin{array}{c}\text { Tempe- } \\
\text { rature } \\
\left({ }^{\circ} \mathrm{F}\right)\end{array}$} & \multirow{3}{*}{$\begin{array}{l}\text { Irriga- } \\
\text { tion } \\
\text { (inches) }\end{array}$} & \multirow{3}{*}{$\begin{array}{l}\text { Soil } \\
\text { data- } \\
\text { base }\end{array}$} \\
\hline & & & \multirow{2}{*}{ No. } & \multicolumn{2}{|c|}{ Size } & & \multirow{2}{*}{ TAWC } & \multirow{2}{*}{ SAT } & \multirow{2}{*}{ Total } & & & & \\
\hline & & & & (feet) & (acres) & & & & & & & & \\
\hline Selah Creek & 1 & DPM & 5,294 & 800 & 14.7 & 116.5 & 5.68 & 7.04 & 12.72 & 9.7 & 47.1 & 2.1 & 1 \\
\hline Selah-Wenas & 2 & DPM & 2,980 & 500 & 5.7 & 25.2 & 3.8 & 9.81 & 13.61 & 9.9 & 49.5 & 24.4 & 1 \\
\hline Cold-Dry & 3 & DPM & 9,254 & 1,000 & 23.0 & 321.3 & 3.0 & 7.62 & 10.62 & 8.4 & 50.0 & 2.4 & 1 \\
\hline Cle Elum & 4 & DPM & 758 & 1,500 & 51.7 & 49.9 & 7.47 & 9.25 & 16.73 & 27.4 & 45.4 & 15.0 & 2 \\
\hline Kittitas & 5 & DPM & 536 & 5,280 & 640.0 & 459.8 & 4.56 & 10.18 & 14.74 & 16.0 & 44.9 & 0.0 & 2 \\
\hline Ellensburg & 6 & DPM & 2,123 & 2,000 & 91.8 & 284.2 & 4.99 & 9.92 & 14.91 & 13.6 & 46.2 & 28.8 & 2 \\
\hline Kiona & 7 & DPM & 6,145 & 1,000 & 23.0 & 211.0 & 3.98 & 9.41 & 13.39 & 7.7 & 52.3 & 13.7 & 1 \\
\hline Satus & 8 & DPM & 5,711 & 800 & 14.7 & 123.6 & 4.93 & 8.25 & 13.22 & 8.1 & 51.8 & 17.6 & 1 \\
\hline lower Naches & 9 & DPM & 7,264 & 600 & 8.3 & 90.4 & 3.39 & 10.69 & 14.08 & 14.3 & 48.2 & 25.8 & 1 \\
\hline Prosser & 10 & DPM & 3,007 & 1,000 & 23.0 & 99.9 & 4.18 & 8.80 & 12.98 & 7.9 & 51.8 & 44.9 & 1 \\
\hline Roza-Sunny & 11 & DPM & 4,920 & 1,200 & 33.1 & 242.4 & 4.61 & 10.74 & 15.35 & 7.3 & 51.5 & 42.5 & 1 \\
\hline Rattle east & 12 & DPM & 3,798 & 1,000 & 23.0 & 129.4 & 4.45 & 8.40 & 12.85 & 9.6 & 48.6 & 10.2 & 1 \\
\hline Toppenish & 13 & DPM & 8,730 & 1,000 & 23.0 & 301.1 & 4.76 & 4.73 & 9.49 & 8.2 & 51.6 & 32.0 & 1 \\
\hline Moxee & 14 & DPM & 6,898 & 800 & 14.7 & 153.0 & 3.5 & 8.14 & 11.64 & 8.3 & 48.6 & 12.7 & 1 \\
\hline Ahtanum & 15 & DPM & 7,060 & 800 & 14.7 & 156.1 & 4.4 & 9.01 & 13.41 & 14.4 & 48.2 & 15.9 & 1 \\
\hline Rattle west & 16 & DPM & 3,380 & 1,000 & 23.0 & 110.4 & 2.15 & 7.47 & 9.62 & 8.3 & 49.1 & 5.0 & 1 \\
\hline Wenas & 17 & DPM & 2,807 & 500 & 5.7 & 23.9 & 3.45 & 9.64 & 13.09 & 12.4 & 49.2 & 21.0 & 1 \\
\hline Naches & 18 & PRMS & 363 & Varies & Varies & 1,107 & 3.47 & 9.49 & 12.96 & 43.0 & 39.1 & 0.0 & 2 \\
\hline upper Yakima & 19 & PRMS & 404 & Varies & Varies & 1,127 & 3.91 & 9.80 & 13.71 & 53.0 & 41.1 & 0.0 & 2 \\
\hline ToppSatus & 20 & PRMS & 242 & Varies & Varies & 1,027 & 3.48 & 9.49 & 12.97 & 17.0 & 46.2 & 0.0 & 2 \\
\hline Yak Canyon & 21 & PRMS & 101 & Varies & Varies & 406.1 & 2.79 & 7.54 & 10.33 & 21.0 & 44.5 & 0.0 & 2 \\
\hline
\end{tabular}


were defined for the combined SSURGO databases. For each soil type, the soil depth, the number of 6-in. soil layers, and the depth-weighted average of the TAWC were calculated. On the basis of the calculated TAWC, the soil attributes of soil texture, saturated water capacity (the amount of available water storage in excess of TAWC to bring the soils to full saturation - the specific yield), and the lateral hydraulic conductivity were estimated.

\section{Land Use and Land Cover}

A USGS national database (Loveland and others, 1991) was used to estimate a dominant LULC for the HRUs in the previously developed PRMS models. The PRMS models include most of the forested lands in the study area, and land covers of shrub or grass occur mainly in two of the modeled areas. The LULC for a HRU was assumed to be applicable for both predevelopment and current conditions in the four areas modeled with PRMS.

Several LULC databases were used to estimate the dominant current LULC condition for the HRUs in the DPM models, which differentiate among different crop types. Reclamation (E. Young, Bureau of Reclamation, written commun., 2003) provided (1) a GIS database for the basin that identified irrigated lands, but not crop type; and (2) databases for crop types for several smaller areas. The Kittitas Conservation District provided a crop-type distribution for most of Kittitas County (Kittitas Conservation District, written commun., 2003) and the South Yakima Conservation District provided information for Roza and Sunnyside Valley Irrigation Districts (fig. 6) (South Yakima Conservation District, written commun., 2004). A LULC for the basin was obtained from the USGS national database (Homer and others, 2004), and this database also provided information on the location of urbanto-low-density residential areas. Detailed crop-type coverage for a small subbasin was developed by the USGS as part of their National Water Quality Assessment Program. A field survey was conducted for the Wapato Irrigation Project (fig. 6) to identify fields planted in orchards, vineyards, and hops. Additional field surveys were conducted in some areas that were identified as irrigated lands from either the Reclamation or the USGS data, but the crop types were not known. Lastly, a 2004 geodatabase was obtained from Washington State Department of Agriculture (DOA), Pesticide Management Division (T. Maxwell, Washington State Department of Agriculture, written commun., 2005). This geodatabase contained information on size of irrigated fields and crop types, aggregated to the section level; thus, the field location within the section could not be determined. This database provided information on the dominant crop type in areas where the LULC was identified as irrigated croplands but the crop type was not known. Most of the crop types in these areas were small grains, hay, pasture, and row crops. Excluding the DOA database, the LULC information was combined into a single spatial database (starting with the least detailed data and substituting in the more detailed data sets) for developing LULC identification numbers for the DPM models.

The database represents a multi-year (approximately 1995-2004) composite LULC that was assumed to be constant for the period of recharge calculations. Information on temporal changes in crop distributions and types and in the distribution of built-up areas was generally not available, especially for years prior to the 1990s, and it would not be computationally feasible to include such information. The LULC in the models, however, allows potential future use of the models to be representative of existing conditions. The potential error in recharge due to using the composite LULC is described in a subsequent section.

An estimated distribution of the natural (predevelopment) vegetative cover was needed to calculate predevelopment recharge using DPM. Most of the areas with human activities within the DPM models are in the semiarid to arid parts of the basin, where a typical native-plant community consists of intermixed sagebrush and grasses; thus the HRUs with human influences were set to a predevelopment cover type of sagebrush.

\section{Irrigation Application Rates}

In DPM, the HRUs with irrigated croplands require as an input the annual application rate of water. Application rates were calculated using two different methods, depending on whether the crops were irrigated with surface-water (principally located within an irrigation district) or with ground water. For surface-water irrigated crops, it was first determined which district a HRU was in. The boundaries of the irrigation districts (fig. 6) in the study area were obtained from Reclamation (E. Young, Bureau of Reclamation, written commun., 2002) and are based on 1974 maps that show irrigation districts in Washington State. The maps included information on the average on-farm deliveries of water (in/yr) and the effective canal losses (in/yr) for a district as a whole. Together, these values were assumed to be the application rate, and provided a consistent and uniform method to estimate rates. For the irrigation districts, the total application rates varied from 32.4 to $86.4 \mathrm{in} / \mathrm{yr}$, with 22 districts having rates of $36 \mathrm{in} / \mathrm{yr}$ and higher, and 16 districts having rates of $42 \mathrm{in} / \mathrm{yr}$ and higher. Although the actual water applied may be less than the allowable/estimated rate, Washington State's water law has a 'use-it or lose-it' (relinquishment) provision. Thus, irrigation water above the amount needed for a particular crop type may be diverted for on-farm use but may not be applied to a field, and is instead discharged to a farm drain or wasteway. It was beyond the scope of this study to estimate how much water is actually applied to the more than 500,000 acres of surfacewater irrigated croplands; a simplified method to indirectly account for potentially unused (not applied) water is described in the following section. 


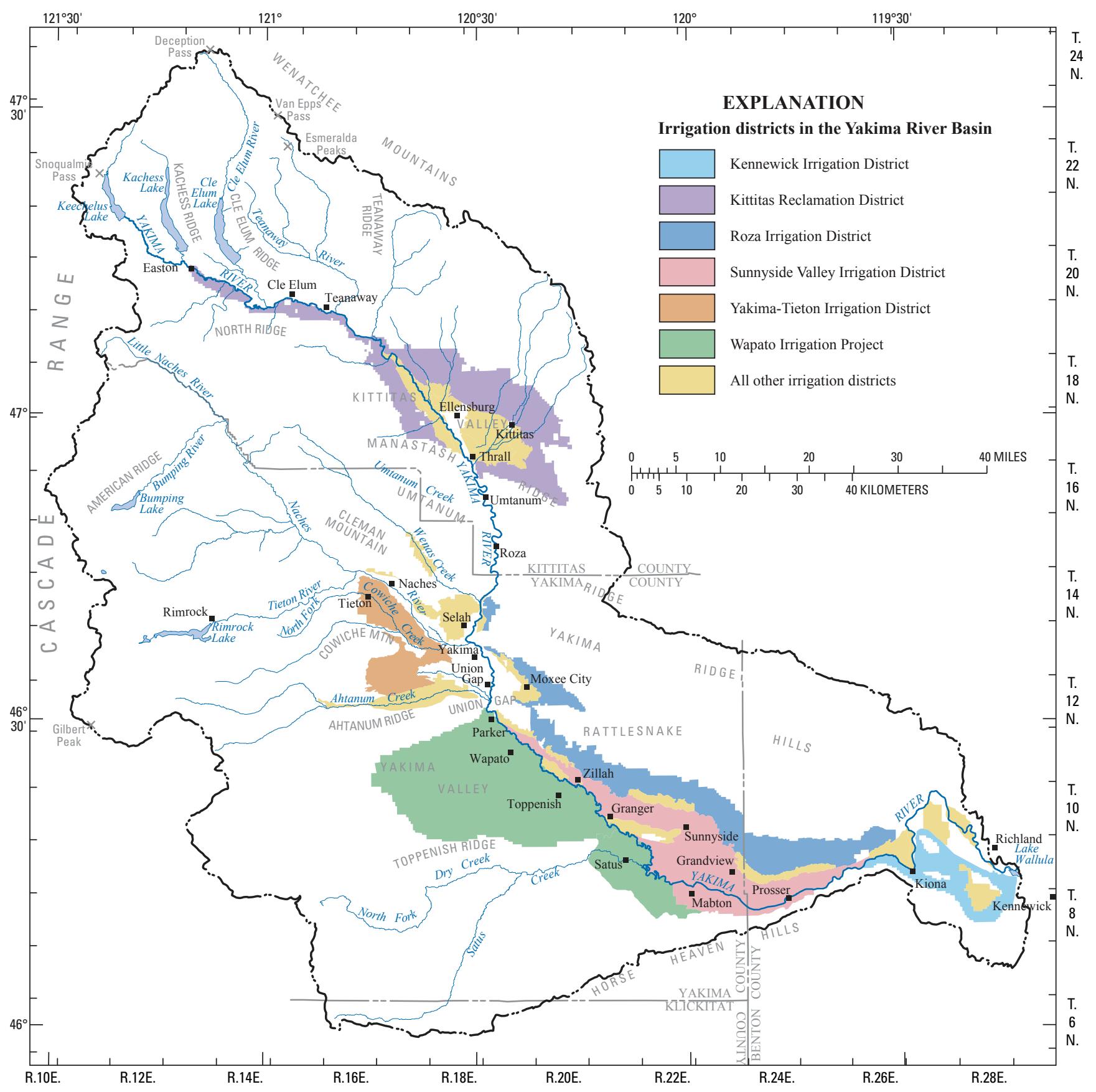

Figure 6. Surface-water irrigation districts, Yakima River Basin, Washington. 
The application rates input to the model for groundwater irrigated crops were estimated on the basis of the dominant crop type for a HRU (a model input parameter) and the estimated long-term average potential water use of that crop. The average potential water use for each crop type was estimated by operating DPM for WYs 1950-2003 for each crop type and averaging the daily values of potential plantwater use (soil moisture non-limiting). These average values were originally calculated by Vaccaro and Sumioka (2006) as part of estimating ground-water pumpage from the aquifer system. The estimated application rates for the ground-water irrigated crops ranged from 15.0 to $38.9 \mathrm{in} / \mathrm{yr}$.

\section{Assumptions and Considerations in Estimating Recharge}

Built-up areas were assumed to be represented by an impervious LULC; accounting for lawn and landscape irrigation in these areas and subsequent recharge of excess applied water was beyond the scope of this study.

A source of recharge that was not simulated by the models is that from septic-system drainfields. Vaccaro and Sumioka (2006) estimated ground-water pumpage from the aquifer system for the Public Water Supply (PWS) systems and for self-supplied domestic households, which was aggregated by the 2000 census blocks of the U.S. Census Bureau (2004). These estimates were annual values for pumpage by the PWS systems, beginning in 1960, or later if the system was established after 1960, and the values were for 5-year increments, beginning in 1960 for the domestic pumpage. Vaccaro and Sumioka (2006) also estimated the monthly distribution of the PWS and domestic pumpage based on a percentage of the annual value; the percentages were calculated using all available data. The months with the lowest percentage of annual pumpage were November through February, and the values ranged from 4.8 to 5.4 percent. The percentage for March, when outdoor use of water starts, was 5.9. Based on the percentages for November through February and assuming that there is a base-level percentage of 5.5 for the months of March through October, about 63 percent of the annual pumpage is for indoor use. About 90 percent (Solley and others, 1988, 1993) of this value was assumed to be the base-level, non-consumptive use of water that was returned to the ground through septic systems; thus about 57 percent of the annual pumpage becomes septic-system recharge. Multiplication of the annual pumpage data by this value gave a distribution of septic-system recharge from 1960 to
2000 by 5-year increments. Values, including PWS, between the 5-year increments, such as 1961-64, were assumed to be constant from the start of the interval, in this case 1960 , until the beginning of the next increment, in this case 1965. Census blocks with 1 acre-ft or less of annual pumpage or that were in the PRMS modeled areas were not included in the calculations. It was assumed that from 1950 to 1960 there was no change in the amount of septic-system recharge. During this period, more that 85 percent of the population growth in the basin occurred in municipalities that do not use septic systems. The basin-wide septic-system recharge from selfsupplied domestic pumpage and PWS (non-sewered) in 1960 was only about 7,000 acre-ft and 2,700 acre-ft, respectively, and a small change from 1950 to 1960 is negligible compared to changes in the other components of recharge. The estimates of septic-system recharge for 2000 were a reasonable approximation for 2001 through 2003. The resulting mean annual distribution of septic-system recharge was added to the mean annual recharge values calculated by DPM.

The three-county (Yakima, Kittitas, and Benton) area that makes up most of the study area contains about 9,500 irrigated fields with different crop types and irrigation methods (T. Maxwell, written commun., 2005). The amount of water actually applied to the fields in surface-water irrigated areas is not known, especially on an annual basis during WYs 1950-2003. In addition, the relinquishment provision in State law and the implementation of Best Management Practices in the basin suggests that the water application rate input to the models may be too large. To reduce the total amount of water that can become recharge, a simplified method was employed in which the application of water to the surface-water irrigated croplands was defined in DPM as being supplied to the crops from above their foliage (sprinkler, center pivot, or wheel line). This allows for more evaporation of the applied water from the intercepted water on the plant foliage, and, in effect, reduces the application rate and ultimately the amount of recharge. Depending on crop type, evaporation can be as much as $10 \mathrm{in} / \mathrm{yr}$. In addition, the application rate was identified in DPM to be constant over the irrigation season and was not based on crop growth, which also reduced calculated recharge.

Irrigation of croplands and other human activities occur in some of the areas modeled using PRMS. For two areas with the most human influences (Cle Elum and Wenas, table 1), boundaries were digitized to define model areas, and DPM models were constructed to estimate recharge for current conditions. The recharge simulated in these models was substituted in place of the recharge calculated by PRMS to estimate the distribution of current-condition recharge. 


\section{Modeled Areas}

The four areas modeled with PRMS include about 3,667 $\mathrm{mi}^{2}$ (about 59 percent of the study area). Most of the upland areas in the basin, which produce more than 95 percent of the natural runoff (Mastin and Vaccaro, 2002a), are included in the upper Yakima, Naches, Yak Canyon, and
ToppSatus areas (fig. 7 and table 1; also U.S. Geological Survey [1998]). The PRMS areas were divided into a total of 1,110 HRUs based on several factors (mean annual precipitation, elevation, soil properties, and left or right stream bank contributing area), and the HRUs vary in size and shape (Mastin and Vaccaro, 2002a).

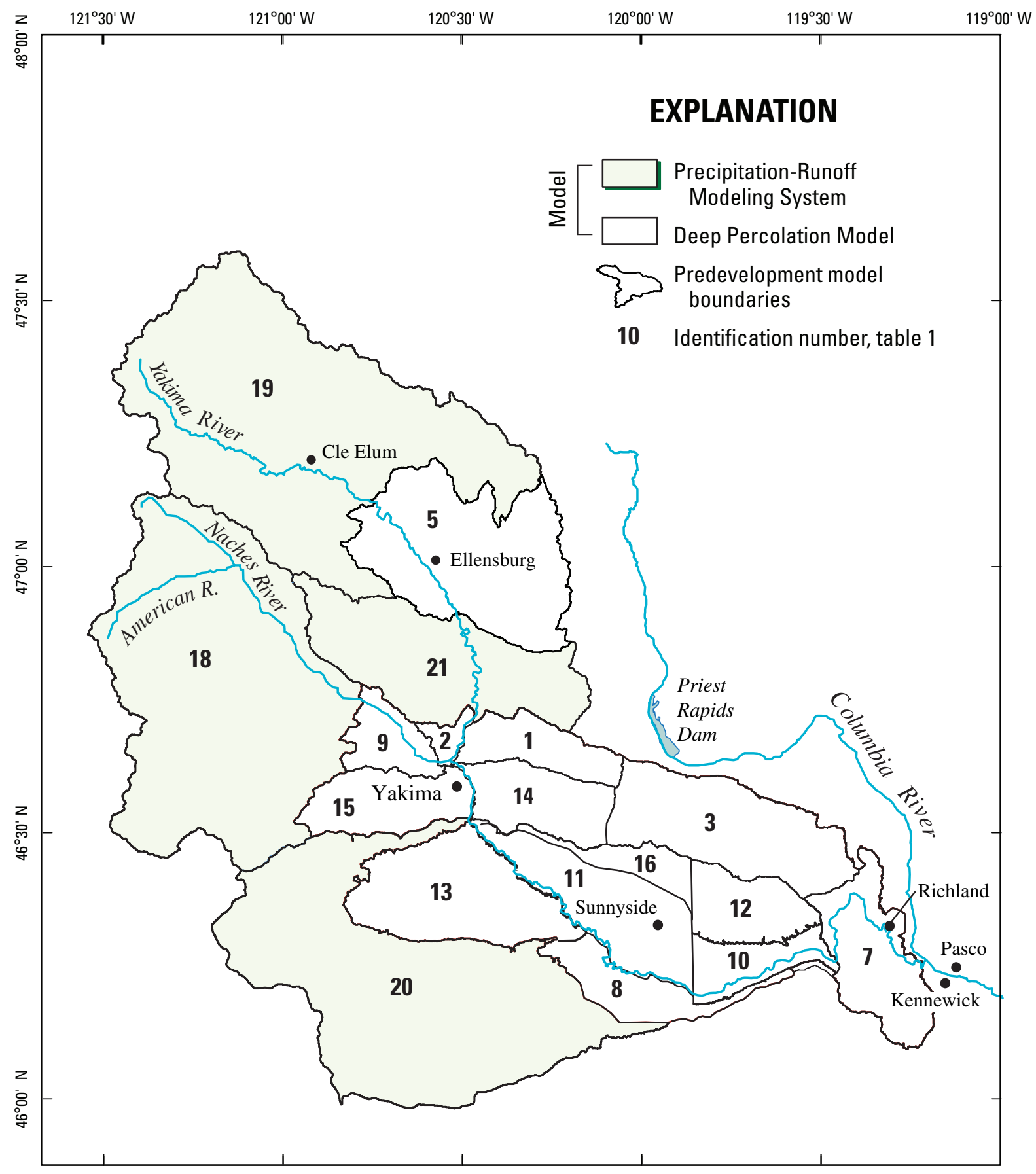

Figure 7. Areas modeled to estimate recharge for predevelopment conditions, Yakima River Basin, Washington. 
Fourteen DPM models were constructed to calculate predevelopment recharge, principally in the areas not included in the PRMS models. The 14 areas (fig. 7) include about $2,554 \mathrm{mi}^{2}$, and were subdivided into a total of 74,978 square HRUs (table 1). Note that because of the irregular-shaped boundaries for the modeled areas, the HRUs at the boundaries are not complete squares. Thirteen of these areas also were modeled using DPM to estimate current-condition recharge. In addition, as described above, two other areas with extensive irrigated agriculture and development included in the PRMS models were modeled using DPM (Wenas and Cle Elum, fig. 8, table 1). One predevelopment area (Kittitas, fig. 7 and table 1) was further refined (Ellensburg, fig. 8 and table 1) to include mainly irrigated croplands and cities for estimating recharge for current conditions. The 16 current-condition models have a total of 80,130 HRUs and include an area of $2,438 \mathrm{mi}^{2}$. The weather information for input to the DPM models was obtained from the weather sites shown on figure 5 .



Figure 8. Areas modeled to estimate recharge for current conditions, Yakima River Basin, Washington. 


\section{Estimates of Ground-Water Recharge}

The estimated mean annual recharge for predevelopment conditions (fig. 9) clearly shows large spatial variations in recharge, from more than 50 in. in the wet uplands to zero in the arid lowlands. The average predevelopment recharge for the entire 6,207 $\mathrm{mi}^{2}$ that was modeled for the Yakima
River Basin aquifer system was estimated to be about 11.9 in. or $5,450 \mathrm{ft}^{3} / \mathrm{s}$ (about 3.9 million acre- $\mathrm{ft}$ ), which is about 44 percent of the total precipitation. About 97 percent of the recharge occurred in the upland parts of the 3,667 $\mathrm{mi}^{2}$ area included in the PRMS models, and nearly 90 percent of the total was in the upper Yakima and Naches modeled areas, herein called the 'humid' areas (fig. 7, tables 1 and 2).

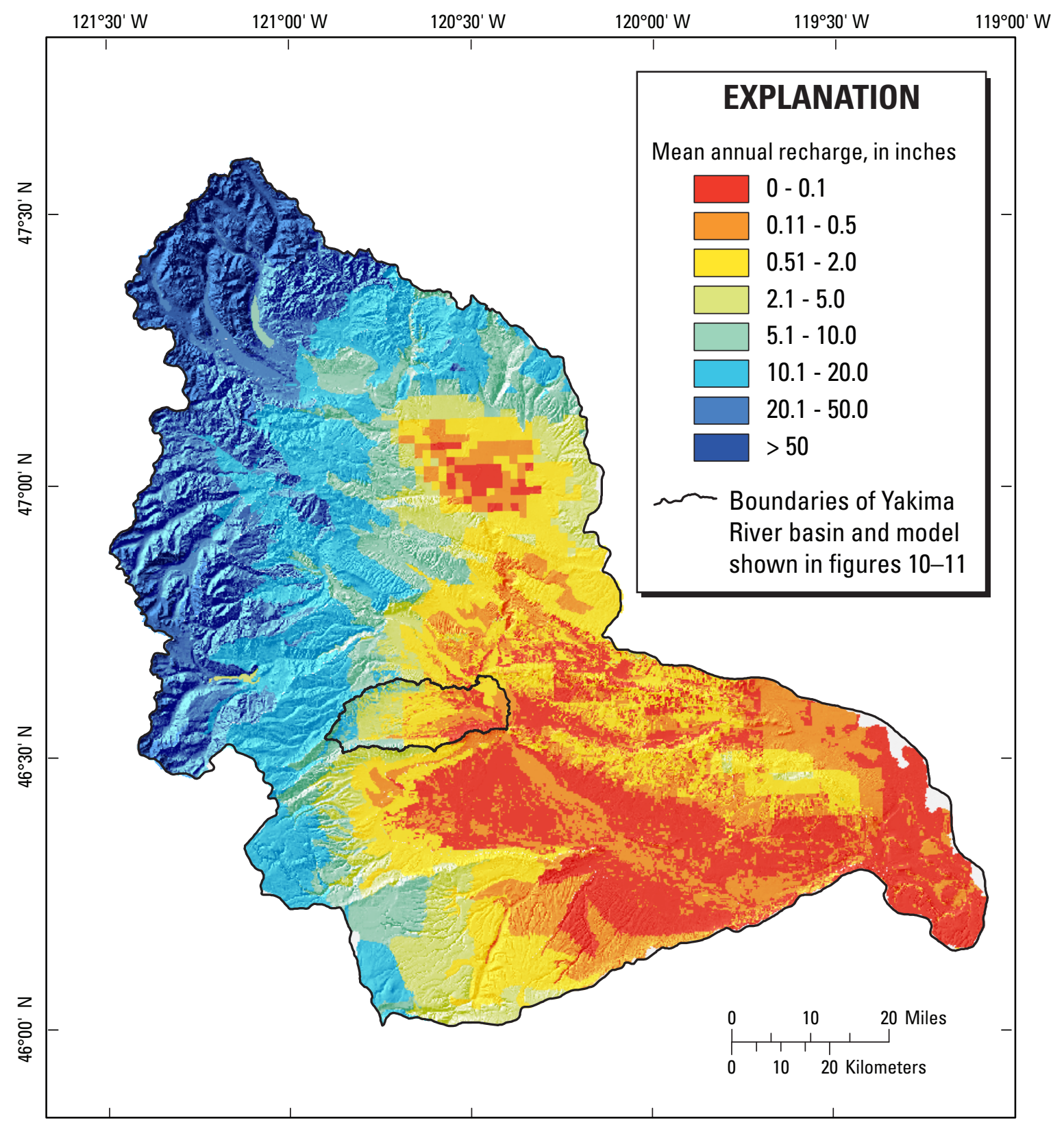

Figure 9. Spatial distribution of mean annual recharge for predevelopment conditions, Yakima River Basin, Washington. 
Table 2. Summary of estimates of mean annual recharge for the modeled areas, Yakima River Basin, Washington.

[Conversions and ratios will not be exact due to rounding. Identification No.: Location of area shown on figures 7 and 8. Condition: P, predevelopment; C, current. Irrrigation: the sum of irrigation application rate and canal/lateral losses. Septic: recharge estimate from septic-system drainfields. AET: modelcalculated actual evapotranspiration and includes evaporation of intercepted water, snow sublimation, soil evaporation, and plant transpiration. I/P: ratio of irrigation to precipitation—no irrigation for predevelopment conditions. R/T: ratio of recharge to total water input—precipitation for predevelopment conditions and precipitation plus irrigation for current conditions. R/P: ratio of recharge to precipitation. R/AET: ratio of recharge to evapotranspiration. Abbreviations: $\mathrm{R}$, recharge; P, precipitation; I, irrigation; T, total water input; in., inch; $\mathrm{ft}^{3} / \mathrm{s}$, cubic foot per second; NA, not applicable]

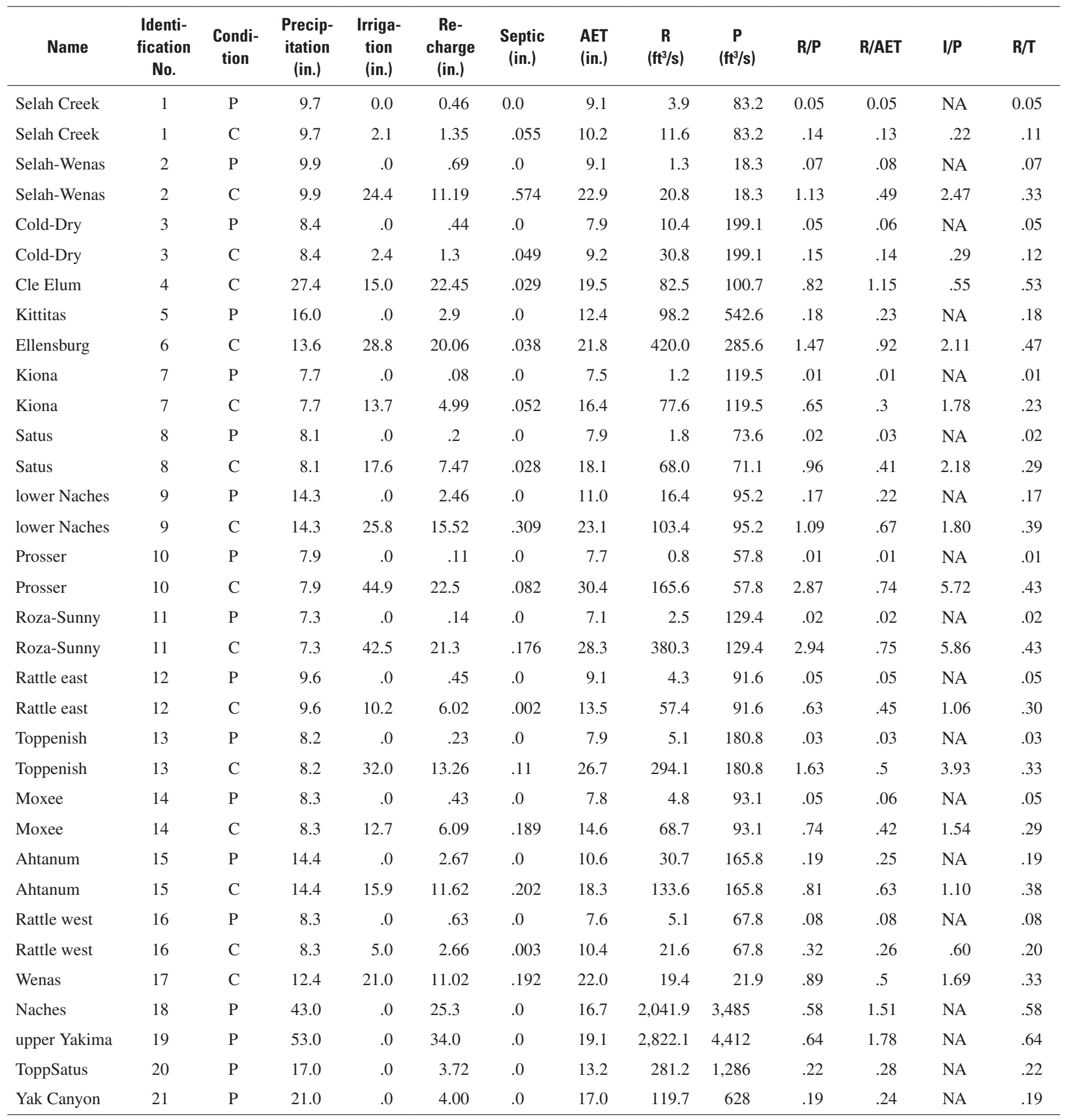


Most recharge in the humid areas discharges as shallow subsurface flow to support streamflow (Mastin and Vaccaro, 2002b) rather than entering the bedrock hydrogeologic units in the uplands. For example, PRMS calculated mean annual inflow to the ground-water reservoirs in the 1,127 $\mathrm{mi}^{2}$ upper Yakima area to be about $960 \mathrm{ft}^{3} / \mathrm{s}$ (about 34 percent of the calculated $2,821 \mathrm{ft}^{3} / \mathrm{s}$ of deep percolation), most of which provides baseflow to streams above Keechelus, Kachess, and Cle Elum Lakes. Inflow to the bedrock units (recharge to the aquifers) in the upland areas is limited because the units generally have low permeability (Molenaar and others, 1980) that is much less than the overlying soils and (or) the unconsolidated deposits are generally thin or missing in these areas (Jones and others, 2006). Estimated mean annual predevelopment recharge was only about $1.0 \mathrm{in}$., or $187 \mathrm{ft}^{3} / \mathrm{s}$ (about 0.14 million acre-ft) for the $2,540 \mathrm{mi}^{2}$ in the 14 areas modeled with DPM. Recharge in these areas, which is about 3 percent of the total basin recharge, was about 10 percent of the precipitation.

The mean annual predevelopment recharge estimates for modeled areas (table 2) vary widely, as do the ratios of recharge to precipitation $(\mathrm{R} / \mathrm{P})$. The large variations in mean annual recharge (0.08 to 33.9 in.) for the areas further highlight the spatial variations shown on figure 9 . For example, recharge in the humid areas was 1 to 2 orders of magnitude larger than that in other areas, and $\mathrm{R} / \mathrm{P}$ was above 0.60 . In contrast, $\mathrm{R} / \mathrm{P}$ ranged from 0.01 to 0.19 for the 14 areas modeled with DPM, of which 11 areas had R/P values of less than 0.10 . One of the smallest recharge estimates, 0.11 in., was for the Prosser area (fig. 7, table 2), where recharge is less than $1 \mathrm{ft}^{3} / \mathrm{s}$ (about 585 acre$\mathrm{ft}$ ) and $\mathrm{R} / \mathrm{P}$ is 0.01 . Intermediate amounts of recharge, 2.16 to 4.00 in., occur in the Ellensburg, ToppSatus, Yak Canyon, lower Naches, and Ahtanum areas, where precipitation was greater than 14 in. (fig. 7 and table 2), and the R/P values were between 0.18 and 0.22 .

Except for the humid areas, the ratio of predevelopment recharge to model-calculated actual evapotranspiration (AET) approximates the R/P values (table 2) because AET accounts for most of the incident precipitation. The model-calculated potential evapotranspiration for the semiarid to arid areas also is much greater than precipitation.

Estimated current recharge increased as a result of human activities (fig. 10). Excluding septic-system recharge (discussed separately below), mean annual current condition recharge was estimated to be 15.6 in., or 7,132 $\mathrm{ft}^{3} / \mathrm{s}$ (5.2 million acre- $\mathrm{ft}$ )—an increase of 3.7 in. or $1,682 \mathrm{ft}^{3} / \mathrm{s}$ (1.2 million acre-ft) from predevelopment conditions. The largest increases in recharge were in areas with the most surface-water irrigation; recharge in some irrigated arid areas was estimated to be similar to the recharge in the humid areas. For example, the Prosser area (predevelopment recharge of 0.11 in.) was estimated to receive about 22.5 in., or $165.6 \mathrm{ft}^{3} / \mathrm{s}$ (about 0.12 million acre- $\mathrm{ft}$ ) of recharge under current conditions (table 2), which is similar to the 25.3 in. of recharge for the humid Naches area. Therefore, under current LULC conditions, recharge is derived primarily from precipitation in the uplands and applied irrigation water in the lowlands.
Excluding recharge from septic-system drainfields, the 16 DPM-modeled areas with extensive human activities (fig. 8) produce about $1,955 \mathrm{ft}^{3} / \mathrm{s}$ of recharge (an increase of about $1,769 \mathrm{ft}^{3} / \mathrm{s}$ from predevelopment conditions for the DPM areas [table 2]). A large part of this quantity, however, is expressed as streamflow in drains and wasteways that ultimately becomes return flow to the streams. These return flows are relied on to meet downstream demands for irrigation and instream flows. Septic systems produce only about $17 \mathrm{ft}^{3} / \mathrm{s}$ (about 12,000 acre-ft) of recharge in these 16 areas, and the basin-wide mean annual septic recharge is about $0.04 \mathrm{in}$. (about 0.2 percent of the total basin average current recharge). Locally, the septic-system recharge can be much greater than precipitation-derived recharge, especially in areas with concentrated population and or with low annual precipitation quantities. For example, a 4-acre census block in the lower Naches area had a population of 293 and a resulting large quantity of septic recharge. Also compare predevelopment recharge to septic recharge for the Selah-Wenas and Ahtanum areas (table 2).

The change in recharge between predevelopment and current conditions is most pronounced for the modeled areas with the most irrigation, but it is also pronounced for areas that are only partly irrigated. For example, LULC for the Ahtanum area (fig. 7, table 2) was estimated to be about 48 percent native sagebrush and grasslands, about 37 percent irrigated (surface water and ground water) agriculture, and about 12 percent high-density development (urban areas, residential, and commercial), with the remaining 3 percent of the area containing several other LULCs. Its average annual water-application rate, 15.9 in. (about $183 \mathrm{ft}^{3} / \mathrm{s}$ ), was about the median for the 16 areas. The spatial distribution of recharge for both LULC conditions (figs. 11-12) indicates the magnitude of the effects of human activities. Precipitation was about $14.4 \mathrm{in}$. and, with the $15.9 \mathrm{in}$. application rate, recharge increased by about 9 in. (103 ft $3 / \mathrm{s})$. Correspondingly, $\mathrm{R} / \mathrm{T}$ (where $\mathrm{T}$ is the total water input - the sum of $\mathrm{P}$ and the application rate) doubled from 0.19 to 0.38 (table 2 ). The relatively uniform distribution of predevelopment recharge (fig. 11) changed dramatically under current conditions (fig. 12), and there are both large increases and some decreases in the areas with high-density development.

On an annual basis, recharge, and the difference between predevelopment and current recharge, vary widely. The annual values for the lower Naches area (fig. 13; location shown on fig. 8) clearly show large interannual variations (more than 5 in.) and the effects of irrigation on model-calculated recharge and AET.

The estimated current recharge in the built-up areas was zero due to the assumption that these areas are impervious LULC. Although this results in areas of no recharge to the aquifer system, most of these areas are surrounded by extensive irrigated lands, and the ground-water levels in the shallow hydrogeologic units would not be representative of areas with zero recharge. 


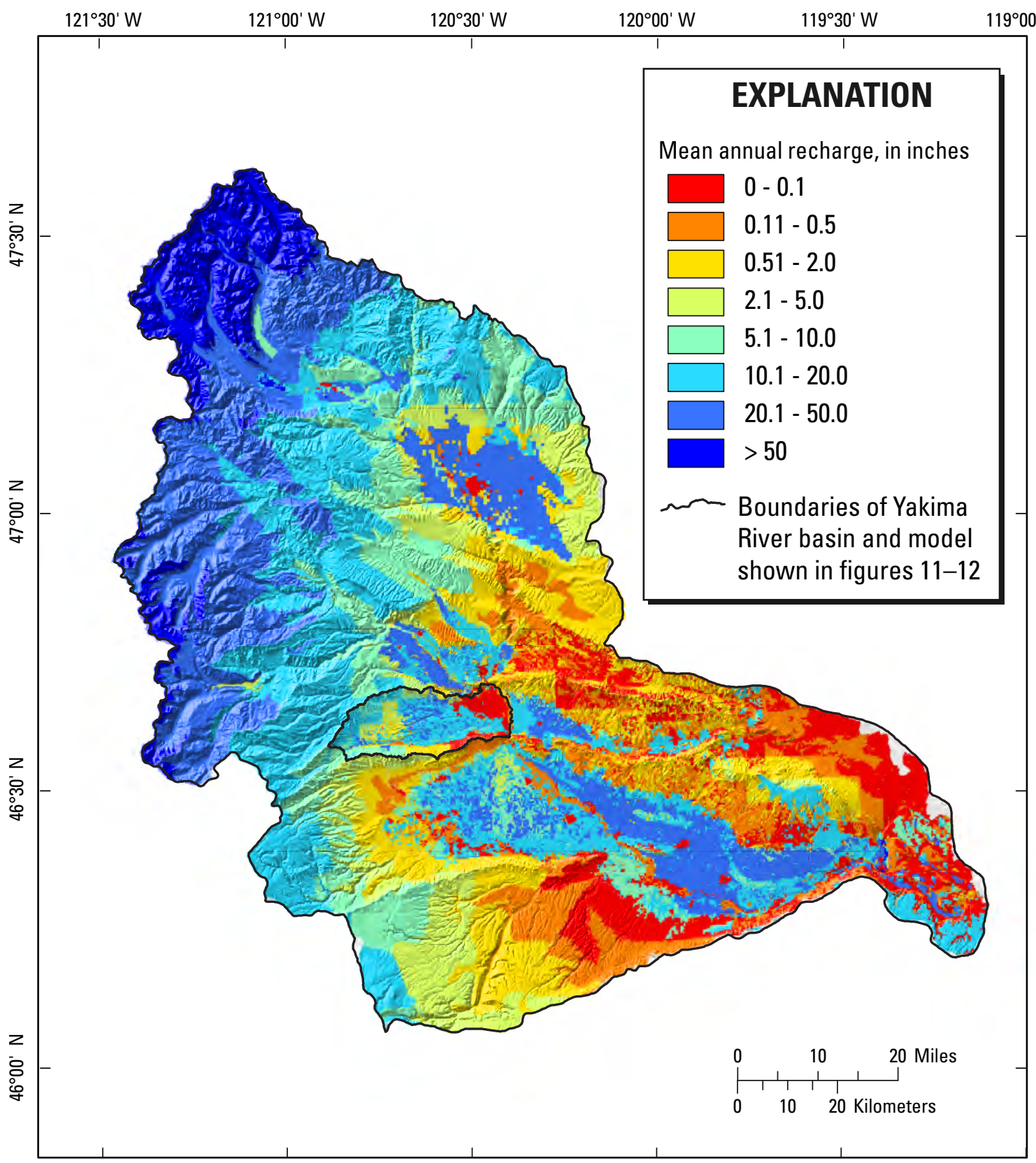

Figure 10. Spatial distribution of mean annual recharge for current conditions, Yakima River Basin, Washington. 


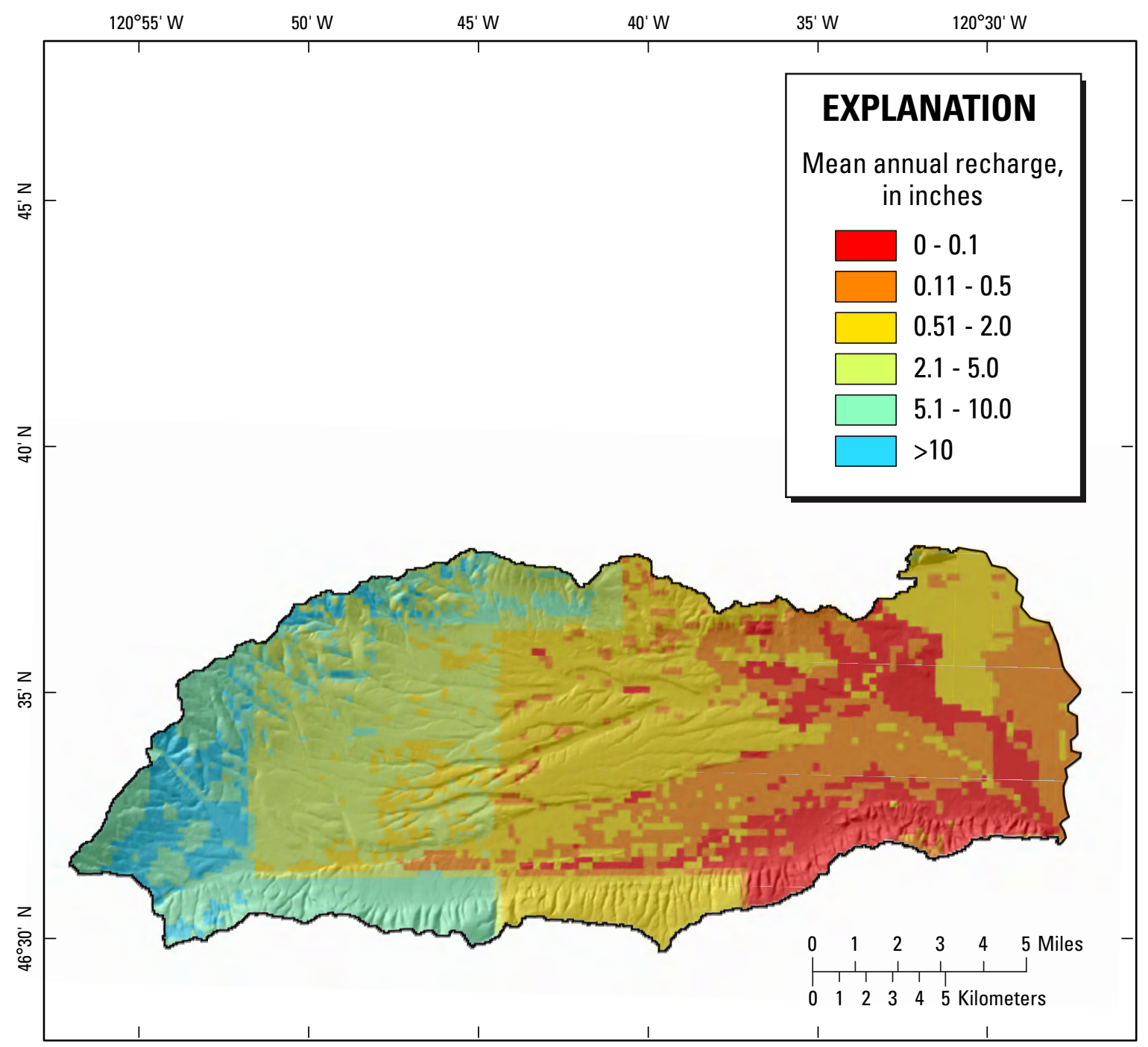

Figure 11. Spatial distribution of mean annual recharge for predevelopment conditions in the Ahtanum area, Yakima River Basin, Washington. 


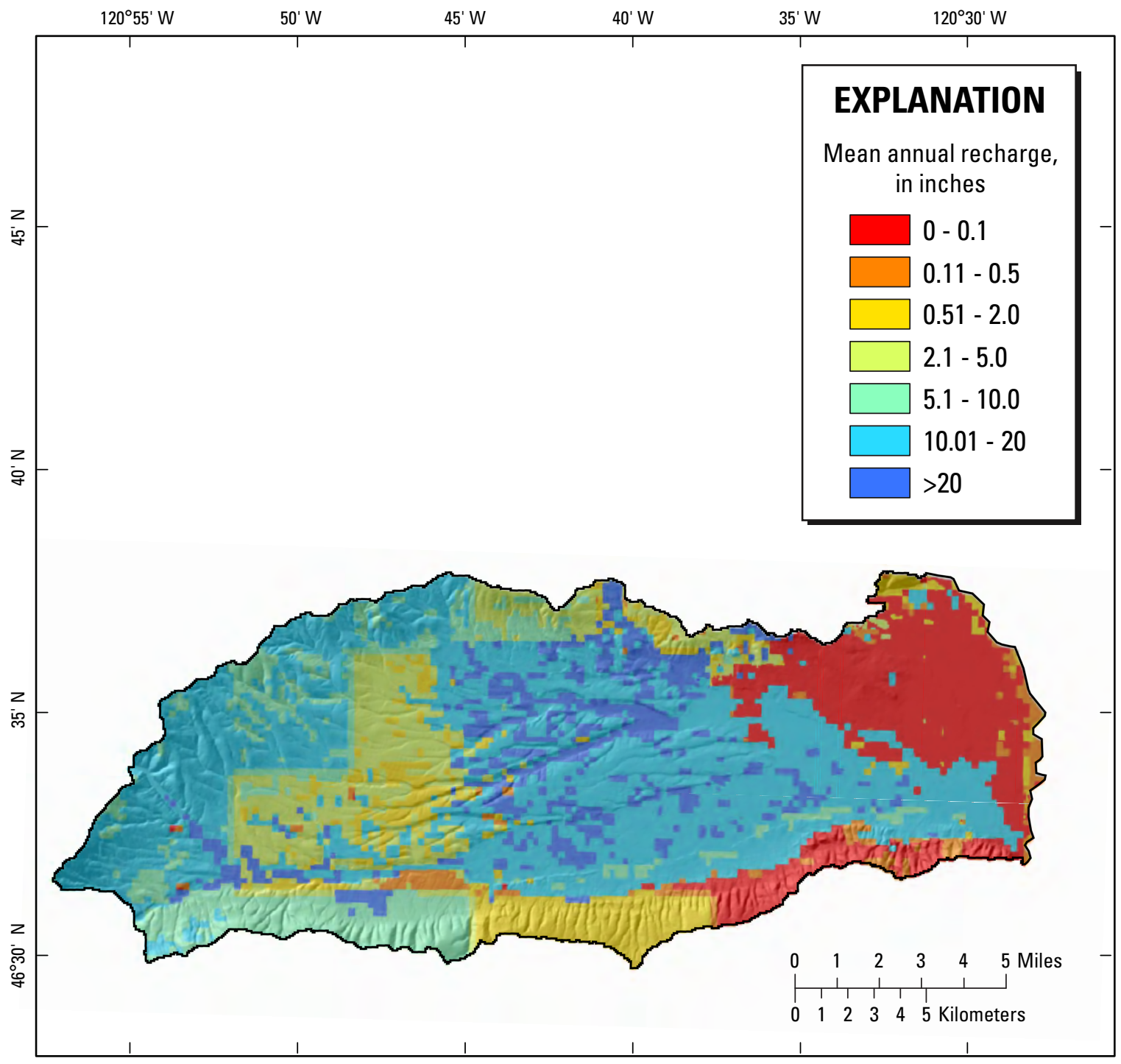

Figure 12. Spatial distribution of mean annual recharge for current conditions in the Ahtanum area, Yakima River Basin, Washington. 


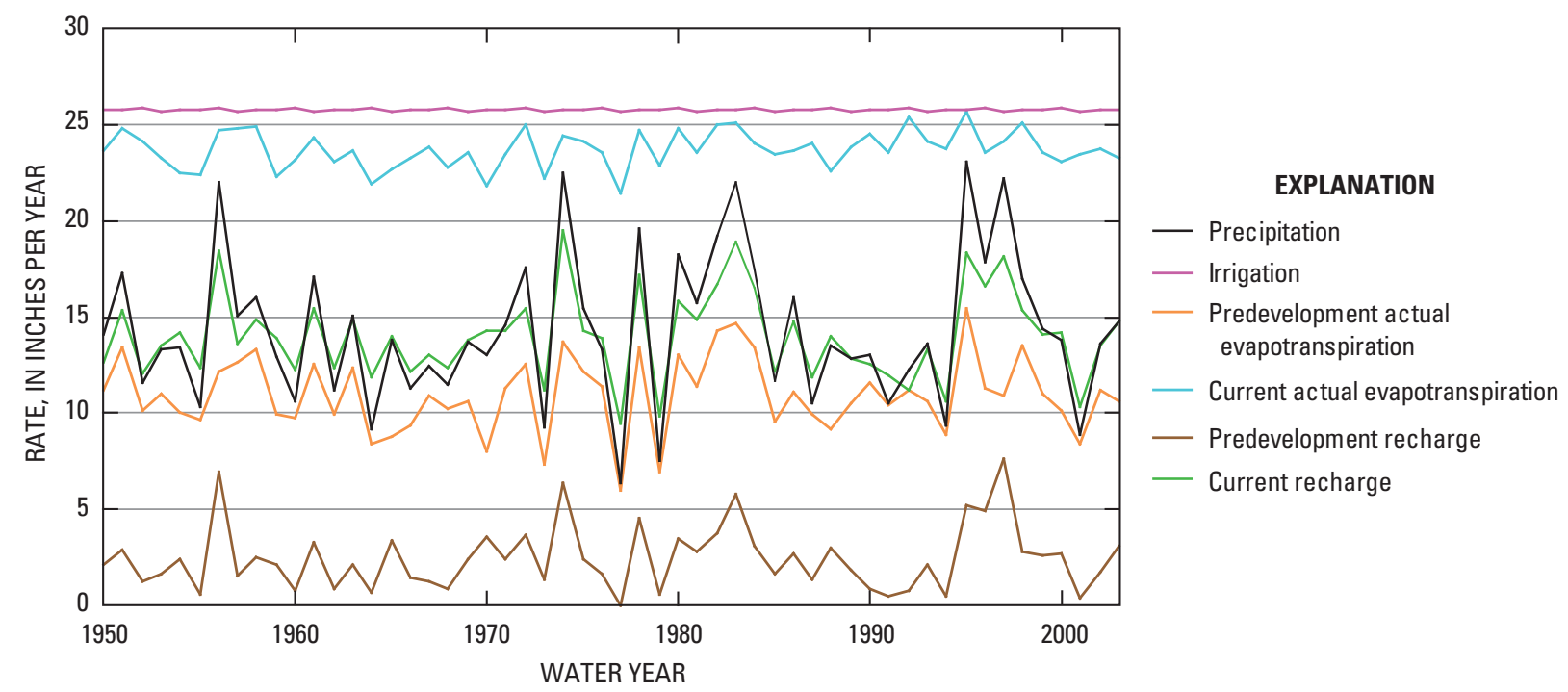

Figure 13. Calculated annual values of selected water-budget components for the lower Naches area.

\section{Factors Controlling Recharge}

The two dominant factors controlling predevelopment ground-water recharge are the quantity and timing of precipitation (including snow accumulation and melt) and the soil properties. Although recharge is affected by the LULC, it is similarly controlled by the quantity of precipitation. For current conditions, the irrigation of croplands is an additional controlling factor. The daily-to-interannual (climate) variability of precipitation, and to some extent air temperature, also influences the amount of recharge under both predevelopment and current conditions.

The relation between mean annual recharge and total water input $(\mathrm{R} / \mathrm{T}$, where $\mathrm{T}$ is total water input: precipitation for predevelopment conditions and precipitation plus irrigation for current conditions) clearly shows the control that the quantity of water input has on recharge (fig. 14 and table 2). Estimated recharge increases nearly linearly from $\mathrm{T}$ quantities of about 7 to about $40 \mathrm{in}$. At $\mathrm{T}$ values larger than about $40 \mathrm{in}$., the relationship is nonlinear due to the effects of: (1) timing of water input, (2) excess water above the amount that can be captured by AET, and (3) soil properties. The timing of water input is best reflected by estimated current recharge for two areas (Prosser and Roza-Sunny areas, tables 1-2) with the largest percentage of irrigated lands. These two areas have a total water input of about 53 and 50 in., respectively, and ratios of irrigation to precipitation (I/P) of more than 5.5; I/P ratios ranged from about 0.2 to 4 for the other areas. During the growing season, crops in the Prosser and Roza-Sunny areas use a larger part of $\mathrm{T}$ in comparison to the upper Yakima area (which has a similar total water input) because the input to the upper Yakima area mainly occurs during the nongrowing season and is not available for AET. This difference also reflects the excess water above the amount that can be captured by AET; note that the potential evapotranspiration is also much lower in the uplands than in the lowlands.
The control that the soils have on recharge is reflected in the relation between mean annual recharge and the ratio of the total quantity of water that can be stored in the root or soil zone (S) to T (fig. 15). The information for figure 15 is only for the areas modeled with DPM, because PRMS does not include a saturated soil-moisture storage compartment. $\mathrm{S}$ is used instead of TAWC because $\mathrm{S} / \mathrm{T}$ values are larger than TAWC/T, and the large amount of irrigation input results in saturated soils (one reason for constructing tile drains, wasteways, and drainage ditches) that are better accounted for by using $\mathrm{S}$. For $\mathrm{S} / \mathrm{T}$ values greater than one, recharge is limited because the mean annual water input is less than the total water storage capacity, and for values less than one, the estimated recharge sharply increases, especially for values less than about 0.6. The estimated average $\mathrm{S}$ for the basin is about 14 in., indicating that, on average, the soils can store about 14 inches of the precipitation falling in the basin. Indeed, the difference between the basin's mean annual precipitation and $\mathrm{S}$ is about $12 \mathrm{in}$., which is nearly equivalent to the estimated mean annual predevelopment recharge.

Mean annual recharge is greater than zero for $\mathrm{S} / \mathrm{T}$ values greater than 1.0 because of the temporal variations in the water input. For example, the Prosser area (fig. 8) has a S/T value of 1.65 and a mean annual predevelopment recharge value of 0.11 in. (table 2) with a large range in annual predevelopment recharge- -35 percent of the annual values were zero, 68 percent were less than 0.01 in., and 85 percent were less than 0.2 in. (fig. 16). These variations are due to both interannual variations in precipitation and its timing; if the precipitation quantity is large or if it occurs over a short period of time, the TWAC may be exceeded, especially during September through March when potential evapotranspiration is low. The non-linearity between ground-water recharge and daily-to-annual precipitation has been described by Rushton and Ward (1979), Stephens and Knowlton (1986), Gee and Hillel (1988), and Bauer and Vaccaro (1990). The non-linearity was a major factor for using daily modeling techniques. 


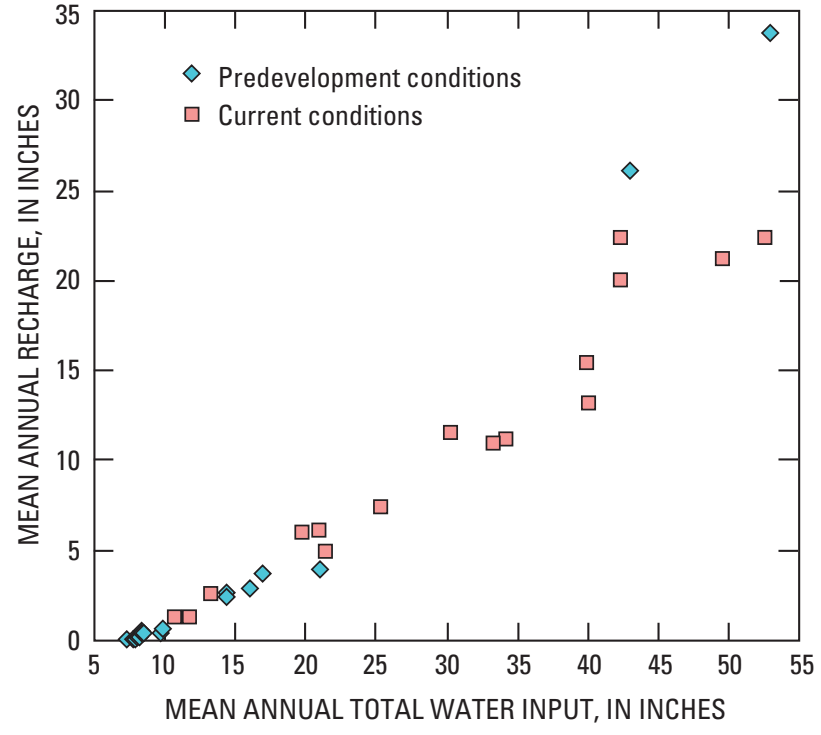

Figure 14. Relation between mean annual recharge and the mean annual total water input (precipitation or precipitation plus irrigation) for the modeled areas for predevelopment and current conditions.

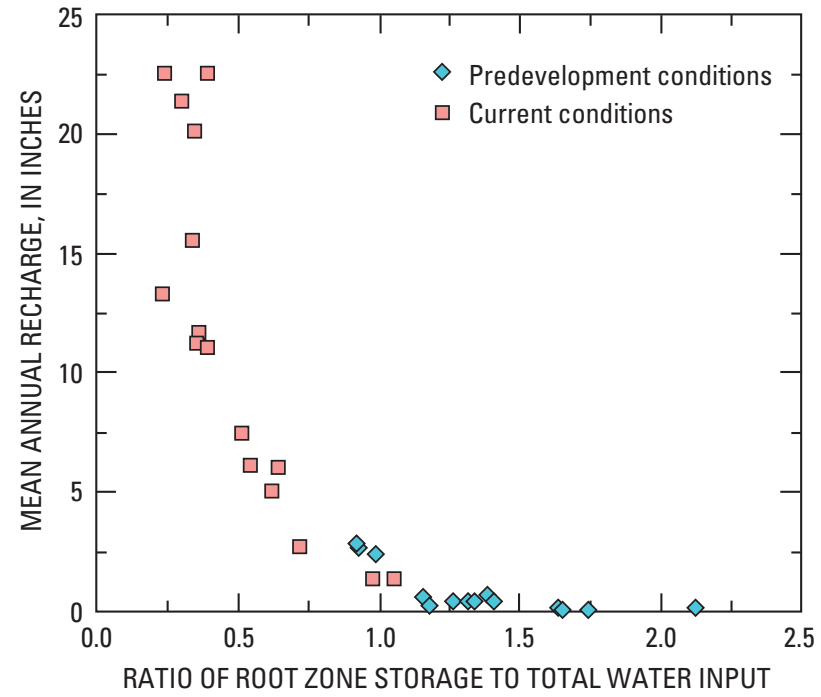

Figure 15. Relation between mean annual recharge and the ratio of the total quantity of water that can be stored in the root zone to the total water input for the areas modeled using the Deep Percolation Model for predevelopment and current conditions.

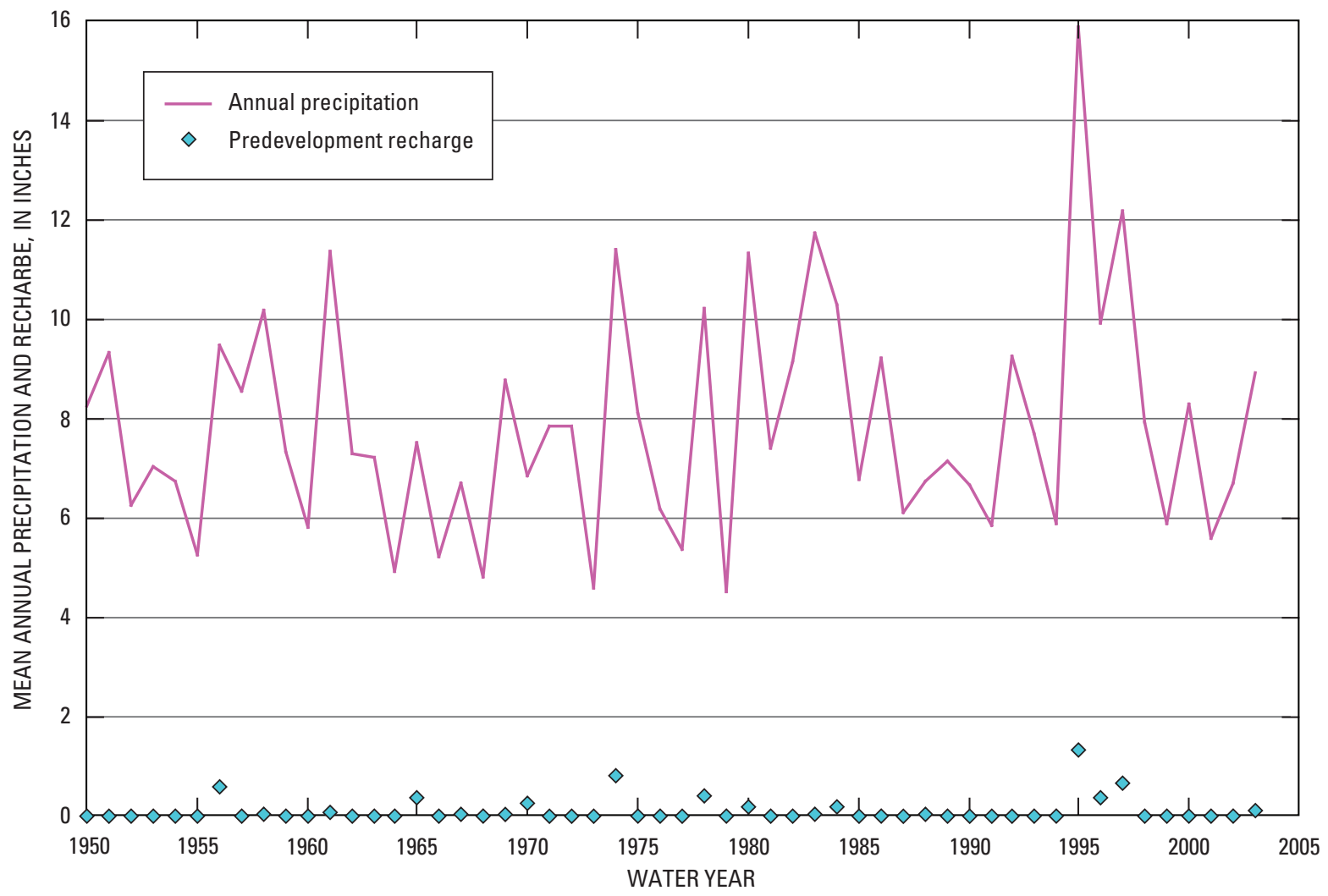

Figure 16. Annual precipitation and estimated predevelopment recharge for the Prosser area, Yakima River Basin, Washington. 


\section{Potential Sources of Error in Recharge Estimates}

Potential sources of error in the estimates of recharge are described by following the flux of water through the landsurface system as calculated by the models. This description starts with the weather data and ends with the water leaving the root or soil zone.

Both errors in the daily weather data and the interpolation of weather data to HRUs produce errors in recharge calculations (Bauer and Vaccaro, 1990). In the uplands, the total annual runoff for a watershed (subbasin) was simulated to be lower in some years and higher in others compared to the observed/estimated value (Mastin and Vaccaro, 2002a); the differences were mainly attributed to the weather data and the interpolation of the data to HRUs. Thus recharge was either under- or over-estimated for such years. However, the simulated and estimated mean annual runoff volume for the basin were similar (Mastin and Vaccaro, 2002a) and the mean annual water budget under predevelopment conditions was reasonable (mean annual recharge was similar to mean annual discharge). Mastin and Vaccaro (2002a) used regression analysis to estimate that about $165 \mathrm{ft}^{3} / \mathrm{s}$ of the mean annual streamflow under predevelopment conditions was produced by the 14 areas modeled with DPM, which is consistent with the mean annual recharge estimate of $187 \mathrm{ft}^{3} / \mathrm{s}$, assuming that most of the recharge ultimately becomes streamflow for these areas. At shorter time scales (daily to annual), both the spatial and temporal distribution of recharge will contain some unknown amount of error due to the weather data and its interpolation.

Estimates of irrigation application rates are another source of error because their quantities are similar to or greater than the precipitation quantities in some areas. The $\mathrm{I} / \mathrm{P}$ ratio ranged from 0.2 to 5.9 and averaged 1.96 for the DPM-modeled areas, and only four areas had I/P ratios of less than 1.0. Therefore, errors in the estimates of irrigation application rates, which averaged about 82 percent of irrigation diversions, can have a large effect on the estimated recharge. Detailed information on irrigation operations (diversion, operational spill, canal/lateral loss, and deliveries) was available for several years for one irrigation district, and the information indicated that for the later years of simulation the effective application rate might be 10 percent too large. If application rates were similarly overestimated in other areas, the estimated recharge rate for the DPM-modeled areas with surface-water irrigation may be more than $1 \mathrm{in}$. too large. The application rates were assumed to be constant over the period of simulation and, although this captures the long-term mean annual recharge, there will be errors for years when the rate was either lower or higher than average. For example, in the severe drought of 2001, much less water than usual was applied in several of the irrigation districts with junior water rights, and thus the recharge estimates would be too large. Conversely, the recharge may be too small during the early years of simulation (typically prior to 1977) because there was a plentiful supply of water for irrigation; differences between annual calculated unregulated and regulated streamflow increase as the unregulated flow increases, indicating that more water is diverted and lost in wet years (Vaccaro, 1986). Assuming that the ratio of $\mathrm{R} / \mathrm{T}$ for an area is applicable if more or less water is applied, and adding or subtracting 4 in. (the range in the potential crop water use for 1950-2003) to the application rate, suggests that using a constant application rate can result in errors of about 10 percent in some years if the application rate was 4 in. too low or too high. In more extreme drought years such as 1992, 1994, and 2001, the recharge estimate may be as much 20 percent too high.

The mean monthly precipitation values for the HRUs were based on a national database of grids that are 4- by 4-km cells (PRISM, Daly and others, 1998), leading to large differences across the boundaries of those grids in areas with large gradients in monthly precipitation. In turn, there are similar changes in the interpolated precipitation values at the HRUs near the grid boundary. As a result, there are differences in calculated recharge values across these boundaries, especially for predevelopment estimates of recharge in the semiarid to arid parts of the study area (see for example, fig. 11). The total estimated mean annual recharge for these areas is reasonable but the spatial distribution will be in error-some areas have recharge values that are too low and other areas have values that are too high. This type of error is a discretization problem due to differences in scale.

The next potential source of error in recharge estimates is the assignment of the LULC to a HRU. For example, under natural conditions, in a typical plant community throughout much of the non-forested parts of the study area, sagebrush and grasses are generally intermixed, with grasses starting to predominate in the forest-transition zone. For predevelopment conditions, the DPM HRUs with human influences (agriculture, urban areas, etc.) were assigned a LULC of sagebrush. Sagebrush, being more deeply rooted than grasses, uses more water, and thus, recharge is less. If a HRU was predominantly grassland instead of sagebrush, the predevelopment recharge estimate would be too small. For current conditions, the LULC was based on the composite LULC database, and several factors can lead to errors in the estimated recharge. Assignment of a low water-use crop type in contrast to a high water-use crop (and the opposite) can lead to both over-estimated and under-estimated recharge and the amount would be dependent on the application rate. Although some error is introduced due to assigning a HRU the wrong LULC, more error is due to assuming that the composite database was valid for all years. The composite distribution does not capture the spatial and temporal changes in crop types and amount of irrigated lands. The potential error would be greater in calculations for the earlier years and less for the surface-water irrigated areas established prior to 1950 and greater for ground-water irrigated areas because of the increase in acres irrigated with ground water since 1950. 
After calculating the amount of precipitation and irrigation water intercepted by plants, soil column calculations are performed on any remaining water (including snowmelt). Therefore, the next important source of error is due to the soil information for each HRU. The largest potential source of error is due to the differences between the generalized STATSGO data and the detailed SSURGO data. The SSURGO data provides more detail both spatially and with depth. STATSGO retains the effective information for the mapped soils in the survey areas, but the actual spatial distribution is coarse. Thus, the total recharge for the models that used the STATSGO data should approximate the actual recharge but there would be errors in the spatial distribution; this is another discretization problem. Differences in hydrologic properties for the same soil-mapping unit occur across some of the boundaries of the different SSURGO survey areas. For example, the same soil-mapping unit may have a high TAWC in one survey area but a low TAWC in the adjacent area, or the soil depths may vary; in either case, calculated recharge would be different across those boundaries. It was beyond the scope of this study to rectify these differences, and thus there are differences in calculated recharge across these discontinuities. Lastly, to simplify the data management and input for estimating recharge for such a large study area, an 'effective' depth-weighted TAWC was calculated for each soil type. This averaging of the TAWC may introduce some error into the estimated recharge, especially for predevelopment conditions in the semiarid to arid areas. For example, if a clay soil layer overlies a sandy soil layer, more water would be retained in the upper clay soil and thus more water would be used by evapotranspiration than calculated by using an averaged value. However, analysis of the layering for selected soil types suggests that any error from such averaging is not large.

The amount of water leaving the root or soil zone is a function of the vertical infiltration rate below the soils for a HRU - the basal (subsoil) rate or infiltration capacity. The rate was estimated to be high for soils overlying coarse-grained deposits and low for soils overlying bedrock. The rate was determined from the depth-to-bedrock information in the soil databases. Shallow soils were assigned a low infiltration rate and deep soils (typically no bedrock) were assumed to overlie deposits with a high infiltration rate. Errors in the identification of this HRU parameter can lead to errors in recharge. In some areas, deep soils may overlie clayey deposits and consequently, the recharge estimate would be too high; in other areas soils may overlie bedrock units with a high infiltration capacity and the recharge estimate would be too low. The potential error in the recharge estimate from misidentification of the infiltration rate is not known, but for much of the area included in the DPM models, the type of underlying deposits is reasonably defined.

Considering all sources of error and the known sensitivity of recharge to different factors (Bauer and Vaccaro, 1990), the error in the recharge estimates for the modeled areas is uncertain. However, mean annual recharge for predevelopment conditions is consistent with the information presented in Mastin and Vaccaro (2002a), and the error for the basin-wide mean annual predevelopment conditions is considered to be on the order of 10 percent. The estimated difference between the mean annual streamflow leaving the basin for predevelopment conditions compared to current conditions is about $2,000 \mathrm{ft}^{3} / \mathrm{s}$, and the estimated increase in mean annual AET from predevelopment to current conditions is about $1,720 \mathrm{ft}^{3} / \mathrm{s}$, suggesting about a 15 percent error in the estimated total mean annual recharge for current conditions. Area-averaged annual recharge values for predevelopment and current conditions likely have an error on the order of 25 percent.

The relative error in recharge values increases with an increase of spatial and temporal resolution. Although the overall spatial distribution of the estimated annual recharge in any modeled area is reasonable, the error in the estimated recharge for a particular HRU can be quite large. Similarly, estimates of daily to monthly recharge likely have larger relative errors than estimates of annual recharge.

\section{Summary and Conclusions}

Recharge was estimated for 6,207 $\mathrm{mi}^{2}$ of the Yakima River Basin aquifer system for predevelopment and current land-use and land-cover conditions to help in assessing water availability and water management and planning. Recharge was estimated using the Precipitation-Runoff Modeling System (PRMS) and the Deep Percolation Model (DPM) that are contained in the U.S. Geological Survey's Modular Modeling System. The models estimated daily values of recharge for water years 1950-98 using four previously developed PRMS models for the mostly forested upland parts of the study area. Daily values were calculated for water years 1950-2003, using 14 DPMs applied to the semiarid to arid lowlands for predevelopment conditions, and using 16 DPMs for current conditions. The daily values of recharge were then aggregated to monthly, annual, mean monthly, and mean annual values.

The mean annual predevelopment recharge was estimated to be about $11.9 \mathrm{in}$., or 5,450 $\mathrm{ft}^{3} / \mathrm{s}$ (about 4 million acre- $\mathrm{ft}$ ). About 97 percent of the recharge was calculated to occur in the upland areas included in the watershed models, but most of this recharge is not available to the bedrock hydrogeologic units. Only about $1.0 \mathrm{in}$., or $187 \mathrm{ft}^{3} / \mathrm{s}$ (about 0.14 million acre-ft) of the total mean annual recharge was estimated to occur in the 2,554 $\mathrm{mi}^{2}$ area included in the deep percolation models. Mean annual recharge for all the modeled areas ranged from 0.08 in. $\left(1.2 \mathrm{ft}^{3} / \mathrm{s}\right)$ to 34 in. $\left(2,822 \mathrm{ft}^{3} / \mathrm{s}\right)$.

The mean annual recharge under current land-use and land-cover conditions was estimated to be about 15.6 in., or $7,132 \mathrm{ft}^{3} / \mathrm{s}$ (about 5.2 million acre-ft). Septic-system drainfields provide another $17 \mathrm{ft}^{3} / \mathrm{s}$ of recharge to the aquifer system. The increase in recharge from predevelopment 
conditions was principally due to the application of irrigation water to croplands. For some of the modeled areas, the irrigation application quantity was more than five times larger than the precipitation quantity. As a result, the ratio of recharge to total water input increased from less than 0.1 to more than 0.5 . Actual evapotranspiration was calculated to have increased by more than $1,700 \mathrm{ft}^{3} / \mathrm{s}$ (about 1.2 million acre-ft). Similar to recharge in the humid areas, additional recharge under current conditions may not be available to deeper aquifers because of shallow sub-surface discharge to drains and wasteways.

The main factors that control predevelopment groundwater recharge are the quantity of precipitation and the soil properties. For current conditions, the land use and land cover and the irrigation of croplands are additional factors. The mean annual predevelopment recharge has a potential error of about 10 percent, and for current conditions, the mean annual recharge error is estimated to be about 15 percent.

\section{Acknowledgments}

The authors wish to thank the Bureau of Reclamation, Bureau of Indian Affairs, and the Washington State Department of Ecology and groups such as conservation districts, irrigation districts, and the Yakama Nation that provided valuable support and access to their records during this study. The authors also thank Steven Wangemann of the Bureau of Indian Affairs for developing the soil database for the Yakama Nation irrigated lands, and Edward Young of the Bureau of Reclamation for providing many Geographic Information System databases and for constructing the initial land use/land cover database from the numerous data sources.

\section{References Cited}

Bauer, H.H., and Mastin, M.C., 1997, Recharge from precipitation in three small glacial-till-mantled catchments in the Puget Sound Lowland, Washington: U.S. Geological Survey Water-Resources Investigations Report 96-4219, 119 p., accessed October, 2006 at http://pubs.er.usgs.gov/ usgspubs/wri/wri964219

Bauer, H.H., and Vaccaro, J.J., 1987, Documentation of a deep percolation model for estimating ground-water recharge: U.S. Geological Survey Open-File Report 86-536, 180 p., accessed October, 2006 at http://pubs.er.usgs.gov/usgspubs/ ofr/ofr86536
Bauer, H.H., and Vaccaro, J.J., 1990, Estimates of groundwater recharge to the Columbia Plateau regional aquifer system, Washington, Oregon, and Idaho, for predevelopment and current land-use conditions: U.S. Geological Survey Water-Resources Investigations Report 88-4108, 37 p., 2 pls., accessed October, 2006 at http://pubs. er.usgs.gov/usgspubs/wri/wri884108

Bureau of Reclamation, 1999, Yakima River Basin Water Enhancement Project, Washington, Final Programmatic Environmental Impact Statement: U.S. Department of Interior, Bureau of Reclamation, Pacific Northwest Region, Upper Columbia Area Office, Yakima, Washington, 197 p.

Cuffney, T.F., Meador, M.R., Porter, S.D., and Gurtz, M.E, 1997, Distribution of fish, benthic invertebrate, and algal communities in relation to physical and chemical conditions, Yakima River Basin, Washington, 1990: U.S. Geological Survey Water-Resources Investigations Report 96-4280, 94 p.

Daly, C. and Taylor, G.H., 1998, 1961-90 mean annual and monthly precipitation maps for the conterminous United States, Oregon Climate Center, on-line on the World Wide Web, May 2000 at http://www.ocs.orst.edu/pub/maps/ Precipitation/prism_ppt.README

Drost, B.W., Whiteman, K.J., and Gonthier, J.B., 1990, The geologic framework of the Columbia Plateau regional aquifer system, Washington, Oregon, and Idaho: U.S. Geological Survey Water-Resources Investigations Report 87-4238, 10 p., 10 sheets.

Flaherty, N.M., 1975, The Yakima Basin and its water: Washington State University, Water Resources Center, Pullman, Wash., 29 p.

Fuhrer, G.J., McKenzie, S.W., Rinella, J.F., Sanzolone, R.F., and Skach, K.A., 1994, Surface-water assessment of the Yakima River Basin in Washington: Analysis of major and minor elements in fine-grained-streambed sediment, 1987, with a section on Geology, by M.W. Gannett: U.S. Geological Survey Open-File Report 93-30, 226 p.

Fuhrer, G.J., Morace, J.L., Johnson, H.M., Rinella, J.F., Ebbert, J.C., Embrey, S.S., Waite, I.T., Carpenter, K.D., Wise, D.R., and Hughes, C.A., 2004, Water quality in the Yakima River Basin, Washington, 1999-2000: U.S. Geological Survey Circular 1237, 44 p.

Gee, G.W., and Hillel, D., 1988, Groundwater recharge in arid regions: Review and critique of estimation methods: Hydrologic Processes, v. 2, p. 255-266.

Glantz, M.H., 1982, Consequences and responsibilities in drought forecasting: The case of Yakima, 1977: Water Resources Research, v. 18, no. 1, p. 3-13. 
Homer, Collin, Huang, Chengquan, Yang, Limin, Wylie Bruce, and Coan, Michael, 2004, Development of a 2001 National Landcover Database for the United States: Photogrammetric Engineering and Remote Sensing, v. 70, no. 7, p. 829-840, accessed October, 2002, at http://www.mrlc.gov/mrlc2k_ product_desc.asp

Jones, M.A., Vaccaro, J.J., and Watkins, A.M., 2006, Hydrogeologic framework of sedimentary deposits in six structural basins, Yakima River Basin, Washington: U.S. Geological Survey Scientific Investigations Report 20065116, 24 p., 7 pls. accessed October 2006, at http://pubs. water.usgs.gov/sir2006-5116

Kratz, M.R., 1978, Dilemmas, disruptions, but no disasterdrought in the Yakima basin, Washington, 1977: State Climatologist for Arizona Climatological Publications, Scientific Paper No. 3, 16 p.

Leavesley, G.H., Lichty, R.W., Troutman, B.M., and Saindon, L.G., 1983, Precipitation-runoff modeling system-users manual: U.S. Geological Survey Water-Resources Investigations Report 83-4238, 207 p., accessed October 2006, at http://pubs.er.usgs.gov/usgspubs/wri/wri834238

Leavesley, G.H., Restrepo, P.J., Markstrom, S.L., Dixon, M., and Stannard, L.G., 1996, The modular modeling system (MMS)_user's manual: U.S. Geological Survey Open-File Report 96-151, 142 p., accessed October 2006, at http:// pubs.er.usgs.gov/usgspubs/ofr/ofr96151

Leavesley, G.H., Viger, R.J., Markstrom, S.L., and Brewer, M.S., 1997, A modular approach to integrating environmental modeling and GIS: Berlin, Germany, in Proceedings of 15th IMACS World Congress on Scientific Computation, Modelling, and Applied Mathematics, no pagination.

Loveland, T.R., Merchant, J., Ohlen, D.O., and Brown, J., 1991, Development of a land cover characteristic data base for the conterminous United States: Photogrammetric Engineering and Remote Sensing, v. 57, no. 11, p. $1453-1463$.

Mastin, M.C., and Vaccaro J.J., 2002a, Documentation of precipitation runoff modeling system modules for the modular modeling system modified for the watershed and river systems management program: U.S. Geological Survey Open-File Report 02-362, accessed December 9, 2002, at http://pubs.water.usgs.gov/ofr02362/

Mastin, M.C., and Vaccaro, J.J., 2002b, Watershed models for decision support in the Yakima River basin, Washington: U.S. Geological Survey Open-File Report 02-404, 46 p., accessed October 2006, at http://pubs.usgs.gov/of/2002/ ofr02404
Meyers, C.W., and Price, S.M., 1979, Geologic studies of the Columbia Plateau, a status report: Rockwell International, Rockwell Hanford Operations RHO-BWI-ST-4, 520 p.

Molenaar, Dee, Grimstead, Peder, and Walters, K.L., 1980, Principal aquifers and well yields in Washington: Washington State Department of Ecology, Geohydrologic Monograph 5, $1 \mathrm{pl}$.

Omernik, J.M., 1987, Ecoregions of the conterminous United States: Annals of the Association of American Geographers, v. 77 , no. 1 , p. 118-125.

Parker, G.L., and Storey, F.B., 1913, Water powers of the Cascade Range, Part III, Yakima River Basin: U.S. Geological Survey Water-Supply Paper 369, 169 p., 18 plates, accessed October 2006, at http://pubs.er.usgs.gov/ usgspubs/wsp/wsp369

Rushton, K.R., and Ward, C., 1979, The estimation of groundwater recharge: Journal of Hydrology, v. 41, p. 345-361.

Soil Survey Staff, Natural Resources Conservation Service, United States Department of Agriculture, undated, Soil Survey Geographic (SSURGO) Database for Yakima River Basin, Washington; accessed October 2000-December 2004, at http://soildatamart.nrcs.usda.gov

Solley, W.B., Merk, C.F., and Pierce, R.R., 1988, Estimated water use in the United States in 1985: U.S. Geological Survey Circular 1004, 82 p.

Solley, W.B., Pierce, R.R., and Perlman, H.A., 1993, Estimated water use in the United States in 1990: U.S. Geological Survey Circular 1081, 76 p.

Stephens, D.B., and Knowlton, B., 1986, Soil water movement and recharge through sand at a semiarid site in New Mexico: Water Resources Research, v. 22, no. 6, p. 801-809.

Systems Operations Advisory Committee, 1999, Report on biologically based flows for the Yakima River basin: Report to The Secretary of the Interior, May 1999, Yakima, Washington, Executive Summary, 6 chapters, Appendix A, variously paginated.

U.S. Census Bureau, 2004, Census 2000 TIGER/Line Data: accessed July 2004 at http://www.census.gov/.

U.S. Department of Agriculture, 1994, State Soil Geographic (STATSGO) Data Base: Data Use information, Soil Conservation Service, National Cartography and GIS Center, Fort Worth, Texas, accessed April, 1997 at http:// dbwww.essc.psu.edu/dbtop/amer_n/us_nw/wa/data/ soilprop/statsgo/doc.html 
U.S. District Court, 1945, Spokane, Washington, Consent decree in the District Court of the United States for the Eastern District of Washington, Southern Division: Civil action No. 21.

U.S. Geological Survey, 1998, Watershed and river systems management program: Application to the Yakima River basin, Washington: U.S. Geological Survey Fact Sheet FS037-98, 4 p., accessed October 2006, at http://pubs.er.usgs. gov/usgspubs/fs/fs03798

U.S. Geological Survey, 2000, National Elevation Dataset, accessed January 2002, at http://seamless.usgs.gov/website/ seamless/products/3arc.asp

Vaccaro, J.J., 1986, Comparison of unregulated and regulated streamflow for the Yakima River at Union Gap and near Parker, Washington. U.S. Geological Survey Open-File Report 82-646, 54 p., accessed October 2006, at http://pubs. er.usgs.gov/usgspubs/ofr/ofr82646

Vaccaro, J.J., 1995, Changes in the hydrometeorological regime in the Pacific Northwest: Proceedings of the Twelfth Annual Pacific Climate Workshop, Asilomar, Cal., Technical Report 46 of the Interagency Ecological Program for the Sacramento-San Joaquin Estuary, p. 143.
Vaccaro, J.J., 2007, A deep percolation model for estimating ground-water recharge: Documentation of modules for the modular modeling system of the U.S. Geological Survey: U.S. Geological Survey Scientific Investigations Report 2006-5318, 30 p.

Vaccaro, J.J., and Sumioka, S.S., 2006, Estimates of groundwater pumpage from the Yakima Basin Aquifer System, Washington, 1960-2000: U.S. Geological Survey Scientific Investigations Report 2006-5205, 56 p.

Viger, R.J., Markstrom, S.L., and Leavesley, G.H., 1997, The GIS Weasel - An interface for the treatment of spatial information used in watershed modeling and water resource management in Proceedings of the First Federal Interagency Hydrologic Modeling Conference, April 19-23, 1998, Las Vegas, Nevada, v. II, chap. 7, p. 73-80.

Washington State Department of Ecology, 1998, Washington State Water Law, A Primer: WR-98-152, accessed October 2000, at http://www.ecy.wa.gov/pubs/98152 
Manuscript approved for publication, January 10, 2007

Prepared by the USGS Publishing Network,

Publishing Service Center, Tacoma, Washington

Bill Gibbs

Chris Janda

Christine Severtson

Bobbie Jo Richey

Sharon L. Wahlstrom

Chet Zenone

For more information concerning the research in this report, contact the Director, Washington Water Science Center

U.S. Geological Survey, 934 Broadway - Suite 300

Tacoma, Washington 98402

http://wa.water.usgs.gov 
